\title{
Securitization rating performance and agency incentives
}

\author{
Daniel Rösch ${ }^{1}$ and Harald Scheule $e^{2,3}$
}

\section{Introduction}

This paper compares and analyzes cross-sectional and time-series characteristics of credit rating agency (CRA) ratings, implied impairment rate estimates and realized impairment rates of asset portfolio securitizations (also known as structured finance transactions). Three distinct hypotheses are analyzed, which provide empirical evidence on the role of ratings for securitizations during the global financial crisis (GFC). ${ }^{4}$ This is of highest importance as shortcomings may have been instrumental to past, current and future loss rates of investors in relation to structured finance transactions, which are generally called securitizations. Structured finance ratings and associated fee revenue have experienced an unprecedented growth in past years. Until the GFC, such ratings were also the dominant rating category - both in terms of numbers of ratings issued as well as CRA fee revenue. ${ }^{5}$

The GFC led to an unprecedented and unexpected increase of impairment rates for securitizations. The disappointment of investors resulted in the criticism of models applied by credit rating agencies (CRAs). Examples are VECTOR from Fitch (see Fitch Ratings (2006)), CDOROM from Moody's (see Moody's Investors Service (2006)) and CDO Evaluator from Standard and Poor's (see Standard and Poor's (2005)). A similar critique was ventured after the Asian crisis of 1997 in relation to corporate bond issuer and bond issue credit ratings. For example, Leot et al (2008) find that ratings follow rather than predict the crisis as systematic downgrades occurred subsequent to the crisis.

1 Institute of Banking \& Finance, Leibniz University of Hannover, Königsworther Platz 1, 30167 Hannover, Germany, Phone: +49-511-762-4668, Fax:+49-511-762-4670. Daniel.Roesch@finance.uni-hannover.de

2 Department of Finance, Faculty of Economics and Commerce, University of Melbourne, Victoria 3010, Australia, Phone: +61-3-8344-9078, Fax: +61-3-8344-6914, hscheule@unimelb.edu.au

3 We would like to thank Louis Ederington, Bruce Grundy, Marty Subrahmanyam and Hans Genberg for valuable suggestions. We would also like to thank the participants of financial seminars at the Deakin University, Deutsche Bundesbank, Global Association of Risk Professionals, University of Innsbruck, University of St. Gallen, Leibniz University Hannover, Macquarie University, Melbourne Centre for Financial Studies and The University of Melbourne as well as the discussants of various conferences for valuable comments. The paper was presented at C.R.E.D.I.T. 2009, the Asian Finance Conference 2009, the International Risk Management Conference 2009, the Australasian Finance and Banking Conference 2009, the 20th Asia Pacific Futures Research Symposium, the 59th Midwest Finance Conference, the 2010 Global Finance Conference, the 2010 FMA European Conference, the 2010 FMA Asian Conference, the 17th Annual Conference of the Multinational Finance Society, Finlawmetrics 2010, the Fourth Annual NUS Risk Management Conference and the Joint BIS/ECB/World Bank Public Investors' Conference 2010. The paper received the Australian Securities Exchange's Best Paper Award on Derivatives and Quantitative Finance in 2009. The support of the Melbourne Centre for Financial Studies and the Hong Kong Institute for Monetary Research is gratefully acknowledged.

4 Namely, the impairment risk, agency incentive and prediction hypotheses, compare Section 2.

5 Rating fee revenue peaked in 2007. According to Table 1, CRA Moody's Investors Services has generated in 2007 a fee revenue of $\$ 873$ million for structured finance ratings, $\$ 412$ million for corporate issuer and issue ratings, \$274 million for financial institution issuer and issue ratings and \$221 million for public project and infrastructure ratings. The relative fee revenues in 2007 (1998) were 49\% (32\%) for structured finance ratings, $23 \%(33 \%)$ for corporate issuer and issue ratings, $15 \%(20 \%)$ for financial institution issuer and issue ratings and $12 \%(15 \%)$ for public project and infrastructure ratings. 
Securitizations involve the sale of asset portfolios to bankruptcy-remote special purpose vehicles, which are funded by investors of different seniorities (tranches). Based on the nature of the securitized asset portfolios, important transaction types include asset-backed securities (ABSs), collateralized debt obligations (CDOs), home equity loan-backed securities (HELs) and mortgage-backed securities (MBSs). Despite their name, securitizations are generally over-the-counter instruments. Information is available to measure the risk of securitizations and includes credit ratings, impairment histories and proxies for the asset portfolio risk, such as asset value indices or cash flow indices. The evaluation of individual risks, their dependence structure and derivatives is complicated by the low liquidity of the underlying assets, the unavailability of secondary markets and the recent origination of such transactions.

Two main streams exist in literature on the measurement of financial risks of securitizations and - with regard to the risk exposure - similar credit derivatives. The first stream focuses on the pricing, where the central issue is to explain observed (market) prices such as credit spreads of credit default swap indices. The most prominent examples are the CDX North America and iTraxx Europe indices, which reference the default events in relation to bond portfolios. These indices were originated in 2003 and 2004. Credit spreads for the indices as well as tranches are generally available daily. Longstaff and Rajan (2008) and Hull and White (2004) apply a risk-neutral pricing framework to develop pricing techniques for these spreads. A central point of these risk models is the specification of the dependence structure for the portfolio assets.

The second stream is concerned with the modeling and estimation of risk characteristics of the underlying asset portfolio without relying on market prices. The focus is on the derivation of the distribution of future asset values (or losses) based on individual risk parameters. In the case of a loan portfolio, the relevant parameters are default probabilities, loss rates given default, exposures at default and dependence parameters such as correlations or more general copulas. Examples are as follows: Merton (1974), Leland (1994), Jarrow and Turnbull (1995), Longstaff and Schwartz (1995), Madan and Unal (1995), Leland and Toft (1996), Jarrow et al (1997), Duffie and Singleton (1999), Shumway (2001), Carey and Hrycay (2001), Crouhy et al (2001), Koopman et al (2005), McNeil and Wendin (2007) and Duffie et al (2007) address the default likelihood. Dietsch and Petey (2004) and McNeil and Wendin (2007) model the correlations between default events. Carey (1998), Acharya et al (2007), Pan and Singleton (2008), Qi and Yang (2009) and Grunert and Weber (2009) develop economically motivated empirical models for recoveries using explanatory co-variables. Altman et al (2005) model correlations between default events and loss rates given default.

Within this stream, credit ratings are often used to explain credit risk. Ratings aim to measure the credit risk of corporate bond issuers, corporate bond issues, sovereigns and structured finance issues. In the contemporary climate of the GFC, the role and importance of ratings to all market participants (eg issuers, investors and regulators), while controversial, is acknowledged. Previous research focuses on the degree to which corporate credit rating changes introduce new information. For example, Radelet and Sachs (1998) find that rating changes are pro-cyclical. This suggests that they provide only a limited amount of new information to the market. Ederington and Goh (1993), Dichev and Piotroski (2001) and Purda (2007) find that corporate credit rating downgrades provide news to the market. Loeffler (2004) finds that the default prediction power of ratings is low. Jorion et al (2005) show that after Regulation Fair Disclosure, the market impact of both downgrades and upgrades is significant and of greater magnitude compared to that observed in the preRegulation Fair Disclosure period. The relative roles of different CRAs have also been studied. For example, Miu and Ozdemir (2002) examine the effect of divergent Moody's and S\&P's ratings of banks and Becker and Milbourn (2009) analyze the link between information efficiency of ratings and competition after the market entry of CRA Fitch. 
With regard to the GFC, Rajan et al (2008) show that omission of soft information in ratings can lead to substantial model risk. Mayer et al (2008) find that the decline of housing prices was responsible for increasing sub-prime mortgage delinquency rates. Benmelech and Dlugosz (2008) analyze collateralized loan obligations (CLOs) rated by Standard and Poor's and find a mismatch between credit ratings and the quality of the underlying loan portfolios. Crouhy et al (2008) point out that CRAs' fee revenues depend on the number of ratings and may be linked to ratings quality. Similarly, Franke and Krahnen (2008) argue that incentive effects have played an important role in the GFC, particularly associated with the allocation of equity tranches of securitizations. Hull (2009) and Hellwig (2008) identify deficient CRA models as a cause of the GFC. Bolton et al (2008) show that the fraction of naive investors is higher, and the reputation risk for CRAs of getting caught understating credit risk is lower during economic booms, which gives CRAs the incentive to understate credit risk in booms.

Unfortunately, the literature has not yet empirically analyzed CRA ratings of securitizations and their accuracy in explaining impairment risk. This may have been due to the complexity of securitizations and the limited availability of data through traditional data sources. Impairment risk is the risk of a securitization to violate contractual payment obligations. Impairment events are a good proxy for the likelihood that an investor in a securitization may experience a loss. ${ }^{6}$ To date, investors and prudential regulators assume the existence of such a link by acknowledging CRAs and assigning risk premia and risk weights to CRA rating categories. This paper addresses the accuracy of CRA securitizations. Based on the rating and impairment data of one CRA, cross-sectional and time-series characteristics of ratings, implied impairment rate estimates and realized impairment rates of asset portfolio securitizations are compared and analyzed.

The remainder of this paper is organized as follows. Section 2 develops the main hypotheses, consistent with the current literature in relation to the risk and uncertainty of CRA assessments. A framework to test the hypotheses is presented. Section 3 describes the data used in the study and analyzes three central hypotheses. Section 4 discusses the major ramifications of the empirical results for securitizations risk models and provides first suggestions in relation to a new stability framework for financial markets, institutions and instruments.

\section{Hypotheses}

The paper aims to answer empirically whether CRA structured finance ratings (from now on referenced as "ratings") are information efficient and may have been causal for the GFC. More specifically, information efficiency will be linked to i) the average impairment risk over time, ii) the impairment risk at and after origination and iii) the impairment risk given the economic cycle.

Rating agencies have been accused of the failure to measure impairment risk, ie the risk that investors may experience losses. Rating agencies address various elements of the asset ( $\mathrm{H} 1 \mathrm{a})$ and liability side (H1b) of securitizations. Impairment Risk Hypotheses are as follows:

H1a: Ratings contain all information about the average asset quality of the asset portfolio relevant for impairment risk such as asset class, resecuritization status and transaction size.

H1b: Ratings contain all information about the characteristics of securitizations relevant for impairment risk, such as subordination level and tranche thickness.

\footnotetext{
6 Note that securitizations are generally structured as specific purpose companies which borrow from investors.
} 
$\mathrm{H} 1 \mathrm{a}$ addresses characteristics of the asset portfolio. Rajan et al (2008) find that securitization risk models omit "soft" information. This implies that CRA ratings, relying on such incomplete models omit important risk factors and hence misevaluate the average credit quality of the asset portfolio. Crouhy et al (2008) suggest that CRAs did not monitor raw data and were tardy in recognizing the implications of the declining state of the sub-prime market and support the argument by Rajan et al (2008) that other asset portfolio characteristics such as soft facts may be important drivers of asset portfolio risk.

$\mathrm{H} 1 \mathrm{~b}$ addresses the tranching structure of securitizations and the current discussion on the appropriate specification of the dependence structure of the asset portfolio, compare Hull (2009), Hellwig (2008). The probability distribution and hence the percentiles of losses associated with the pool are particularly sensitive to the correlations in the underlying asset pool. Thus, the level of subordination may be a key driver and should explain tranche impairments after controlling for credit ratings if correlations are mis-specified in the CRA model.

Furthermore, the rating agencies may have an incentive to bias the measures of impairment risk. Crouhy et al (2008) argue generally that CRA fees are paid by issuers and that CRA competition is limited by regulation. This may imply that the credit quality measured by a CRA and CRA fee revenue is positively correlated. However, CRAs publish default and rating migration tables, which are used to calibrate ratings to metric risk measures. Thus, a systematic "rating for fee" policy would be noticed and priced by investors when analyzing the financial risk in relation to ratings. $\mathrm{H} 2$ addresses two potential ways in which rating agencies may circumvent this rating performance mechanism. Our Agency Incentive Hypotheses are:

H2a: Rating-implied impairment risk and time since origination are positively correlated.

H2b: Rating-implied impairment risk and rating intensity at origination are negatively correlated.

The first incentive problem $(\mathrm{H} 2 \mathrm{a})$ relates to the assumption that investors do not price the risk with regard to origination and monitoring years. Rating performance measures are generally calculated as an average per rating class. The fee revenue of rating agencies is high when the first rating is generated (origination year) and low in later years when ratings are revisited (monitoring years). Figure 1 shows the origination volume and outstanding volume of the analyzed tranches as well as the CRA fee revenue. ${ }^{7}$ It is apparent and insightful that despite the fact that CRAs provide origination and monitoring ratings, CRA fee revenue corresponds with the origination volume rather than the outstanding volume.

7 Please note that outstanding volume as well as fee revenue relate to origination years and monitoring years while the origination volume relates to origination years only. 
Figure 1

\section{Origination volume, outstanding volume and CRA structured finance fee revenue}

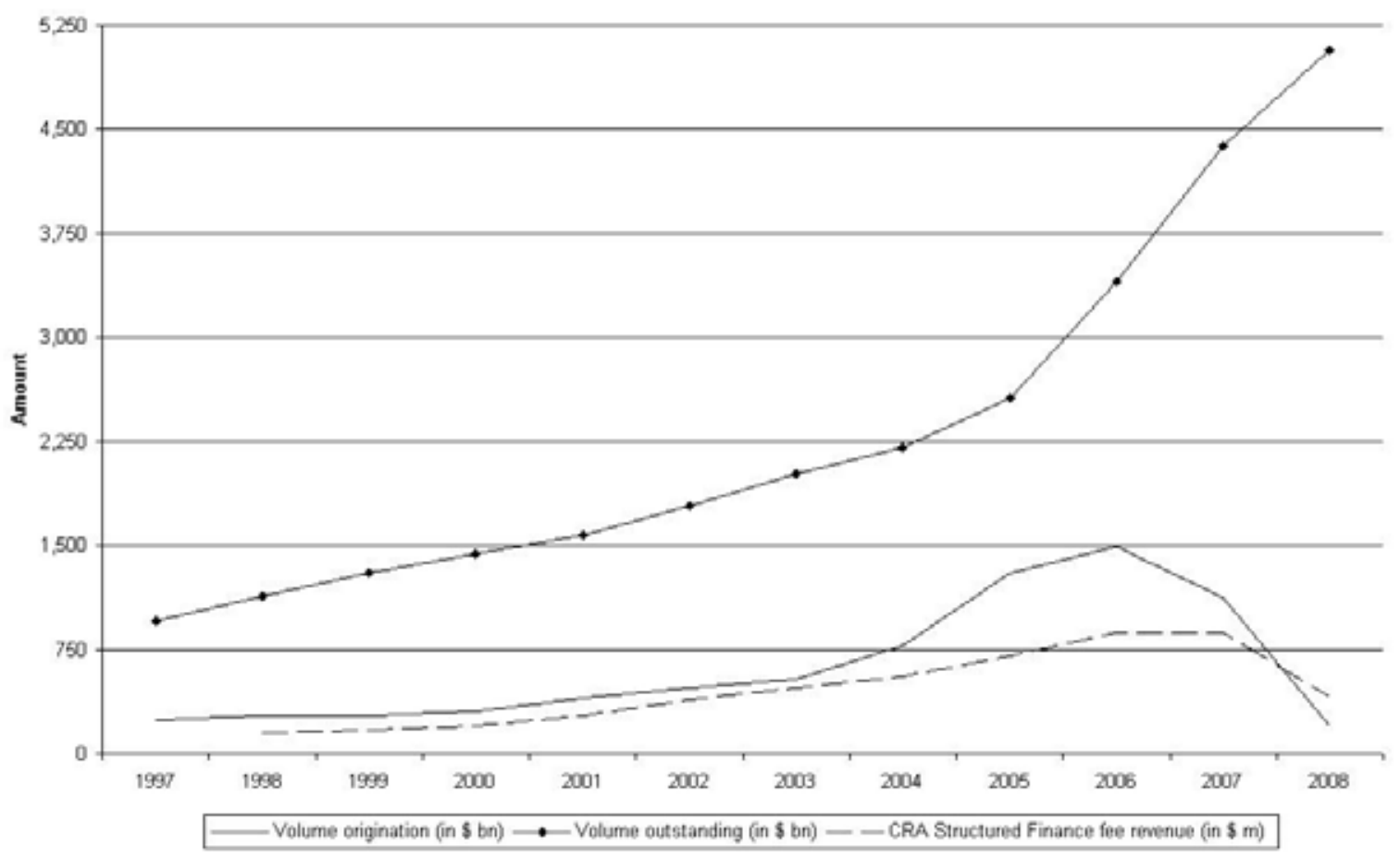

This chart shows the origination volume, outstanding volume and structured finance fee revenue of the CRA Moody's Investors Service. Origination volume relates to the year starting from the time that a rating was first assigned. Origination volume has increased prior to the GFC and decreased during the GFC. Outstanding numbers relate to issues which are rated at the beginning of the year and hence are originated in prior years. Outstanding volume has increased during the whole observation period. Origination volume and structured finance fee revenues have increased prior to the GFC and decreased during the GFC. Therefore, structured finance fee revenue coincides more with the origination volume which is in line with the recognition of the majority of fee revenue at or shortly after origination by the CRA.

The reason for this finding is that origination fees exceed the monitoring fees in absolute terms. ${ }^{8}$ In addition, the fees in relation to origination and monitoring years are often paid upfront despite their lagged recognition as accounting income. As a result, CRAs may have an incentive to assign i) too low risk ratings in origination years to increase fee revenue and ii) too high risk ratings in monitoring years to maintain stable default and rating migration performance measures. The hypothesis tests whether the underestimation of risk decreases over time since origination.

The second incentive problem $(\mathrm{H} 2 \mathrm{~b})$ relates to a critique by Bolton et al (2008) who suggest that the fraction of naive investors is higher, and the reputation risk for CRAs of getting caught understating credit risk is lower during economic booms, which gives CRAs the incentive to understate credit risk in economic booms. Figure 1 supports this argument

8 In financial year 2007, CRA Moody's Investors Service generated $77 \%$ of fee revenue for origination of ratings and $23 \%$ for monitoring of ratings. The empirical data suggests that $37 \%$ of structured finance ratings relate to an origination year and $63 \%$ of structured finance ratings relate to a monitoring year. These numbers imply that an origination rating generates approximately 5.7 times more fee revenue than monitoring a rating for one year. 
visually by showing that the origination volume and thus fee volume is high in economic booms.

Hence $\mathrm{H} 2 \mathrm{~b}$ tests whether impairment risk is underestimated during periods of high securitization activity at origination.

$\mathrm{H} 3$ addresses the information degree of credit ratings and their ability to forecast impairment risk. Hellwig (2008) argues that the omission of systematic factors related to real estate prices such as interest rates and the availability of housing finance may have led to an overoptimism of valuations and ratings. Such expectations may be adjusted in an economic downturn. Consequently, credit ratings which are overoptimistic and do not account for all relevant risk factors are poor predictors for impairment risk. Thus our Prediction Hypothesis is:

\section{H3: Ratings predict impairment risk.}

Please note that the Impairment Risk Hypotheses $\mathrm{H} 1 \mathrm{a}$ and $\mathrm{H} 1 \mathrm{~b}$ relate to idiosyncratic risk. The Agency Incentive Hypotheses $\mathrm{H} 2 \mathrm{a}$ and $\mathrm{H} 2 \mathrm{~b}$ relate to incentive mechanisms induced by the fee structure for securitization ratings. The Prediction Hypothesis $\mathrm{H} 3$ relates to the interaction between idiosyncratic and systematic risk characteristics of securitizations.

Following the models in Gordy (2000), Gordy (2003), McNeil and Wendin (2007), and Gupton et al (1997), the attachment probability (ie the propensity of being exposed to a loss in the underlying asset pool) for a tranche $i$ of transaction (or asset pool) $j$ in period $t$ $\left(i=1, \ldots, I_{j} ; j=1, \ldots, J, t=1, \ldots, T\right)$ is approximated by

$$
\begin{aligned}
P\left(D_{i j t}=1\right) & =1-\Phi\left(\frac{\sqrt{1-\rho} \Phi^{-1}\left(A L_{i j t}\right)-\Phi^{-1}\left(\pi_{i t}\right)}{\sqrt{\rho}}\right) \\
& =\Phi\left(\frac{-\sqrt{1-\rho} \Phi^{-1}\left(A L_{i j t}\right)+\Phi^{-1}\left(\pi_{i t}\right)}{\sqrt{\rho}}\right) \\
& =\Phi\left(\eta_{i j t}\right)
\end{aligned}
$$

which implies that the tranche impairment probability is a function of the

- $\quad$ Average portfolio asset quality $\pi_{i t}$;

- $\quad$ Asset correlation $\rho$;

- $\quad$ Attachment level of a tranche relative to the total deal principal $A L_{i j t}$.

Please note that $\eta_{i j t} \equiv \frac{-\sqrt{1-\rho} \Phi^{-1}\left(A L_{i j t}\right)-\Phi^{-1}\left(\pi_{i t}\right)}{\sqrt{\rho}} ; i=1, \ldots, l_{j} ; j=1, \ldots, J, t=1, \ldots, T$.

Reasonable assumptions in this body of literature are the modeling of credit risk of an individual borrower by a Gaussian factor model for the individual asset return based on Merton (1974) as well as a large number of assets in the pool.

All three hypotheses test whether CRAs capture impairment risk accurately. If credit ratings correctly assess the impairment risk of a tranche, then the tranche impairment probability should solely be explained by the ratings. 
The impairment of tranche $i \quad\left(i=1, \ldots, l_{j}\right)$ of pool $j(j=1, \ldots, J)$ in time $t \quad(t=1, \ldots, T)$ is linked with observable information by the probit regression ${ }^{9}$

$P\left(D_{i j t}=1\right)=\Phi\left(\beta^{\prime} \chi_{i j t}\right)$

where $\chi_{i j t}$ is a vector of tranche ratings at the beginning of an observation period. $\beta$ is the respective vector of sensitivities and includes an intercept.

The models may be used for forecasting as the CRA ratings are measured at the beginning of the observation year. Note that the left hand side is the same probability as in equation (1). If ratings fully explain the impairment probability, then no other variable besides the ratings should be significant in the probit regression. In other words, if ratings reflect the tranche impairment probability accurately, they should include the information as specified in equation (1).

However, if a rating omits information, then additional information besides the rating may explain the tranche impairment probability. Examples may relate to the asset portfolio quality, the securitization structure as well as observable information about the business cycle. Consider an error in assigning one or more of the pool parameters resulting in $\tilde{\eta}_{i j t} \neq \eta_{i j t}$ which will lead to a bias in the estimated impairment probability. Then the impairment probability can be written as

$P\left(D_{i j t}=1\right)=\Phi\left(\tilde{\eta}_{i j t}+\Delta_{i j t}\right)$

with $\Delta_{i j t} \equiv \eta_{i j t}-\widetilde{\eta}_{i j t}$ denoting the measurement error in pool variables which may refer to characteristics of the pool, the tranche or time. Model (3) will provide the basis for the empirical tests in the following section.

Please note that this paper focuses on the ability of ratings and other risk factors to explain the (binary) impairment risk. Thus, the above probit analysis is appropriate to compare ratings and impairment events as it links the probability of impairment with explanatory variables. Krahnen and Weber (2001) argue that such a link is a necessity under generally accepted rating principles. These types of models have also been employed in other studies for analyzing corporate bond issue and issuer ratings or bank's loan credit ratings, compare eg Grunert et al (2005). ${ }^{10}$

\section{Empirical analysis}

\subsection{Structured finance data}

The paper analyzes a comprehensive panel data set of structured finance transactions rated by CRA Moody's Investors Service. The data covers characteristics of asset portfolios (which

$9 \quad$ The models were also estimated for robustness using only one tranche per pool to analyze the dependence between multiple tranches in relation to a single asset portfolio. The results are qualitatively similar to the ones presented.

10 The research question is slightly different to the analysis of rating standard dynamics. One important study in this area is by Blume et al (1998) who analyze corporate rating standards and find that such rating standards have become more stringent from 1978 to 1995. Rating standard is defined in this study as the propensity to assign a certain rating category and thus an ordered probit models is estimated where the ratings grades are the dependent variables. Another example for such an approach is Becker and Milbourn (2008). 
are also known as collateral portfolios), characteristics of tranches, ratings of tranches as well as occurrences of impairment events of tranches.

The focus of the present study is on the performance of CRA ratings, which involves a comparison of CRA ratings with the likelihood of occurrence of impairment events. An impairment event is defined as (compare Moody's Investors Service (2008)):

"[...] one of two categories, principal impairments and interest impairments.

Principal impairments include securities that have suffered principal write-downs or principal losses at maturity and securities that have been downgraded to $\mathrm{Ca} / \mathrm{C}$, even if they have not yet experienced an interest shortfall or principal write-down. Interest impairments, or interest-impaired securities, include securities that are not principal impaired and have experienced only interest shortfalls."

Alternative measures for rating performance may exist. Firstly, ratings may be compared to the performance of the asset portfolios. The approach may be reasonable for asset portfolios such as mortgage-backed securities where information on the default rates of the underlying portfolios is available. We chose not to follow this approach for two reasons. Firstly, we focus on the securitization market rather than mortgage-backed securities only and find distinct differences between various asset portfolios. Secondly, credit ratings are issued for individual securities (tranches) and a key element in credit ratings is the credit enhancement (subordination) of these securities.

Secondly, ratings may be compared to the propensity of occurrence of rating downgrades. We chose not to follow this approach as our research question aims to analyze the accuracy of credit ratings. Analyzing rating downgrades limits the interpretation of results as the link between downgrades and losses to investors is less transparent.

Structured finance transactions are very heterogeneous by definition. The authors are aware of potential prudential policy implications of the research project and applied the seven filter rules to generate a homogeneous data set. Hence, the following observations are deleted:

(1) Transaction observations which can not be placed into the categories ABS, CDO, CMBS, HEL or RMBS. These are mainly asset-backed commercial paper, structured covered bonds, catastrophe bonds, and derivative product companies. $22.0 \%$ of the original number of observations are deleted;

(2) Transaction observations where the monetary volume and therefore relative credit enhancement and thickness of individual tranches could not be determined without setting additional assumptions due to i) multiple currency tranches and ii) missing senior unfunded tranche characteristics. $13.5 \%$ of the original number of observations are deleted after the application of filter rule (1);

(3) Transaction observations which are not based on the currency USD or transaction observations which are not originated in the USA. 5.0\% of the original number of observations are deleted after the application of filter rule (1) and (2);

(4) The time horizon is 1997-2008. Tranche observations which relate to years prior to 1997 due to a limited number of impairment events. Impairment events are the focus of this paper and years prior to 1997 have experienced few impairment events. Years after 2008 are not yet available at the time of writing this paper. Some $7.3 \%$ of the original number of observations are deleted after the application of filter rule (1) to (3);

(5) Tranche observations which have experienced an impairment event in prior years. $0.2 \%$ of the original number of observations are deleted after the application of filter rule (1) to (4). 
The resulting data comprise 325,443 annual tranche observations. The number of impaired tranche observations is $13,072 .^{11}$ The data set is one of the most comprehensive data sets on securitization collected to date.

Table 1 shows various proxies for origination ${ }^{12}$ and outstanding volume of the data: number of tranches, number of deals and volume. In addition, rating fee revenues of the CRA Moody's Investors Service are shown. The outstanding number relates to issues which are rated at the beginning of the year and hence originated in prior years. Outstanding volume has increased during the whole observation period. Origination volume and structured finance fee revenues have increased prior to the GFC and decreased during the GFC. Therefore, structured finance fees coincide more with the origination volume which is in line with the recognition of the majority of fee revenue at or shortly after origination by the CRA. ${ }^{13}$

Table 1

Origination volume, outstanding volume and CRA structured finance fee revenue, various categories

\begin{tabular}{r|r|r|r|r|r|r|r|r|r|r}
\hline & \multicolumn{2}{|c|}{ Origination volume } & \multicolumn{2}{c|}{ Outstanding volume } & \multicolumn{3}{c}{ CRA fee revenue (in \$ m) } \\
\hline Year & Tranches & Deals & $\begin{array}{r}\text { Volume } \\
\text { (in \$ bn) }\end{array}$ & Tranches & Deals & $\begin{array}{r}\text { Volume } \\
\text { (in \$ bn) }\end{array}$ & SF & Corporate & Financials & PPI \\
\hline 1997 & 2,704 & 582 & 243 & 10,957 & 2,958 & 959 & & & & \\
1998 & 2,501 & 559 & 269 & 12,839 & 3,360 & 1,130 & 143 & 144 & 90 & 65 \\
1999 & 2,665 & 574 & 271 & 13,855 & 3,702 & 1,298 & 172 & 166 & 105 & 60 \\
2000 & 2,674 & 582 & 302 & 14,941 & 3,944 & 1,441 & 199 & 163 & 112 & 46 \\
2001 & 4,533 & 761 & 402 & 16,309 & 4,193 & 1,579 & 274 & 226 & 131 & 64 \\
2002 & 5,727 & 855 & 477 & 18,814 & 4,536 & 1,782 & 384 & 228 & 155 & 81 \\
2003 & 6,783 & 1,014 & 537 & 21,416 & 4,888 & 2,012 & 475 & 267 & 181 & 87 \\
2004 & 9,599 & 1,189 & 781 & 22,728 & 5,065 & 2,202 & 553 & 300 & 209 & 82 \\
2005 & 16,597 & 1,617 & 1,301 & 28,302 & 5,438 & 2,565 & 709 & 277 & 214 & 185 \\
2006 & 19,929 & 1,827 & 1,491 & 41,247 & 6,312 & 3,401 & 873 & 336 & 233 & 198 \\
2007 & 12,958 & 1,405 & 1,126 & 57,661 & 7,511 & 4,380 & 873 & 412 & 274 & 221 \\
2008 & 1,014 & 231 & 199 & 66,374 & 8,453 & 5,067 & 411 & 301 & 263 & 230 \\
\hline Total & 87,684 & 11,196 & 7,399 & 325,443 & 60,360 & 27,816 & 5,066 & 2,817 & 1,967 & 1,319 \\
\hline
\end{tabular}

This table shows the Origination volume, outstanding volume and structured finance fee revenue of the CRA Moody's Investors Service. Origination numbers relate to the year starting from the time that a rating was first assigned. Origination numbers have increased prior to the GFC and decreased during the GFC. Outstanding numbers relate to issues which are rated at the beginning of the year and hence originated in prior years. Outstanding numbers have increased during the whole observation period. SF stands for structured finance (securitization) rating revenues and PPI stand for Public, Project \& Infrastructure rating revenues. SF rating fee revenues have increased prior to the GFC and decreased during the GFC.

\footnotetext{
11 The original data set included 15,083 impairment events before the application of filtering rules.

12 Origination volume relates to the year starting from the time that a rating was first assigned.

13 Compare footnote 5.
} 
From the resulting raw data, the following categorical variables were generated:

- Impairment (1: impairment, 0: no impairment) indicates that a tranche is impaired in the observation year;

- $\quad$ Rating at the origination of the transaction (Aaa, Aa, A, Baa, Ba, B, Caa) reflects the risk of a tranche and is measured at the beginning of an observation year, ${ }^{14}$

- $\quad$ Rating at the beginning of the respective year (Aaa, Aa, A, Baa, Ba, B, Caa) reflects the risk of a tranche and is measured at the beginning of an observation year;

- Deal category (ABS: asset backed security, CDO: collateralized debt obligation, CMBS: commercial mortgage-backed security, HEL: home equity loan security, RMBS: residential mortgage-backed security); ${ }^{.15}$

- $\quad$ Resecuritization (1: resecuritization, 0: no resecuritization) indicates whether a transaction is a resecuritization of previous transactions. These transactions are often called 'squared' (e.g., CDO-squared). The database allows for the identification of resecuritizations for CDO and MBS transactions;

- $\quad$ Deal size: indicates the inflation-adjusted logarithm of the size of the underlying asset portfolio;

- $\quad$ Subordination indicates the relative size (in relation to the deal size) of the tranches that are subordinated to the respective tranche;

- $\quad$ Thickness indicates the relative size (in relation to the deal size) of the respective tranche;

- $\quad$ Origination year: year in which a tranche was first rated which coincides with the year in which transaction was closed;

- $\quad$ Time since origination (TSO) indicates the time in years since a tranche was first rated;

- $\quad$ Securitization volume at origination (SVO) indicates logarithm of the volume of rated tranches for a given year. ${ }^{16}$

Table 2 and Table 3 describe the number of observations over time. The overall number of rated securitizations has increased at an increasing rate over time. ${ }^{17}$

14 In the empirical analysis, the rating categories Aaa to A are aggregated to category Aaa-A due to the limited number of past impairment events in these categories.

15 In the empirical analysis, the categories RMBS and CMBS are aggregated to category MBS due to the limited number of past impairment events in these categories.

16 Alternative indicators of origination volumes such as the number of originated tranches or transactions were tested for robustness and resulted in similar results.

17 All tables weight individual transactions equally and similar observations may be made for the value of securitizations. 
Table 2

Total number of observations, relative frequencies of ratings at origination and at the beginning of the year

Panel A: Rating at Origination

\begin{tabular}{c|c|c|c|r|r|r|r|l}
\hline Year & All & \multicolumn{1}{c|}{ Aaa } & \multicolumn{1}{c|}{ Aa } & \multicolumn{1}{c|}{ A } & \multicolumn{1}{c|}{ Baa } & Ba & B & Caa \\
\hline 1997 & 10,957 & $69.66 \%$ & $16.72 \%$ & $6.20 \%$ & $5.04 \%$ & $1.58 \%$ & $0.80 \%$ & $0.00 \%$ \\
1998 & 12,839 & $69.41 \%$ & $15.02 \%$ & $6.82 \%$ & $5.97 \%$ & $1.79 \%$ & $0.97 \%$ & $0.01 \%$ \\
1999 & 13,855 & $67.10 \%$ & $13.95 \%$ & $7.87 \%$ & $7.28 \%$ & $2.41 \%$ & $1.34 \%$ & $0.04 \%$ \\
2000 & 14,941 & $64.86 \%$ & $12.76 \%$ & $8.96 \%$ & $8.49 \%$ & $3.00 \%$ & $1.84 \%$ & $0.09 \%$ \\
2001 & 16,309 & $62.50 \%$ & $12.17 \%$ & $9.91 \%$ & $9.67 \%$ & $3.59 \%$ & $2.06 \%$ & $0.10 \%$ \\
2002 & 18,814 & $60.31 \%$ & $11.45 \%$ & $10.73 \%$ & $11.04 \%$ & $4.26 \%$ & $2.10 \%$ & $0.10 \%$ \\
2003 & 21,416 & $57.49 \%$ & $11.26 \%$ & $11.95 \%$ & $12.16 \%$ & $4.70 \%$ & $2.32 \%$ & $0.11 \%$ \\
2004 & 22,728 & $53.78 \%$ & $11.39 \%$ & $13.38 \%$ & $13.89 \%$ & $4.90 \%$ & $2.55 \%$ & $0.11 \%$ \\
2005 & 28,302 & $51.08 \%$ & $12.06 \%$ & $14.12 \%$ & $15.21 \%$ & $4.98 \%$ & $2.47 \%$ & $0.07 \%$ \\
2006 & 41,247 & $50.04 \%$ & $13.48 \%$ & $13.88 \%$ & $15.43 \%$ & $5.14 \%$ & $1.99 \%$ & $0.04 \%$ \\
2007 & 57,661 & $47.43 \%$ & $15.07 \%$ & $14.48 \%$ & $15.86 \%$ & $5.46 \%$ & $1.66 \%$ & $0.03 \%$ \\
2008 & 66,374 & $47.25 \%$ & $16.18 \%$ & $14.38 \%$ & $14.89 \%$ & $4.99 \%$ & $2.02 \%$ & $0.29 \%$ \\
\hline Total & 325,443 & $58.41 \%$ & $13.46 \%$ & $11.06 \%$ & $11.25 \%$ & $3.90 \%$ & $1.84 \%$ & $0.08 \%$ \\
\hline
\end{tabular}

Panel B: Rating at the beginning of a year

\begin{tabular}{c|c|c|r|r|r|r|r|c}
\hline Year & All & Aaa & \multicolumn{1}{c|}{ Aa } & \multicolumn{1}{c|}{ A } & \multicolumn{1}{c|}{ Baa } & Ba & B & Caa \\
\hline 1997 & 10,957 & $72.09 \%$ & $13.50 \%$ & $6.74 \%$ & $4.74 \%$ & $1.93 \%$ & $1.00 \%$ & $0.00 \%$ \\
1998 & 12,839 & $72.57 \%$ & $11.37 \%$ & $7.24 \%$ & $5.76 \%$ & $1.94 \%$ & $1.11 \%$ & $0.01 \%$ \\
1999 & 13,855 & $70.70 \%$ & $10.04 \%$ & $8.05 \%$ & $6.79 \%$ & $2.79 \%$ & $1.52 \%$ & $0.10 \%$ \\
2000 & 14,941 & $68.04 \%$ & $9.46 \%$ & $9.02 \%$ & $8.33 \%$ & $2.94 \%$ & $1.93 \%$ & $0.28 \%$ \\
2001 & 16,309 & $65.95 \%$ & $9.01 \%$ & $9.97 \%$ & $8.92 \%$ & $3.78 \%$ & $2.13 \%$ & $0.25 \%$ \\
2002 & 18,814 & $63.03 \%$ & $9.00 \%$ & $10.76 \%$ & $10.28 \%$ & $4.44 \%$ & $2.21 \%$ & $0.27 \%$ \\
2003 & 21,416 & $58.92 \%$ & $9.51 \%$ & $11.88 \%$ & $11.67 \%$ & $4.89 \%$ & $2.68 \%$ & $0.44 \%$ \\
2004 & 22,728 & $53.96 \%$ & $10.35 \%$ & $13.20 \%$ & $13.21 \%$ & $5.31 \%$ & $3.24 \%$ & $0.74 \%$ \\
2005 & 28,302 & $51.24 \%$ & $11.25 \%$ & $13.86 \%$ & $14.39 \%$ & $5.34 \%$ & $3.05 \%$ & $0.87 \%$ \\
2006 & 41,247 & $50.70 \%$ & $12.81 \%$ & $13.56 \%$ & $14.66 \%$ & $5.31 \%$ & $2.34 \%$ & $0.62 \%$ \\
2007 & 57,661 & $48.61 \%$ & $14.61 \%$ & $14.00 \%$ & $14.91 \%$ & $5.51 \%$ & $1.93 \%$ & $0.44 \%$ \\
2008 & 66,374 & $48.23 \%$ & $15.63 \%$ & $12.12 \%$ & $12.68 \%$ & $6.16 \%$ & $3.89 \%$ & $1.29 \%$ \\
\hline Total & 325,443 & $60.34 \%$ & $11.38 \%$ & $10.87 \%$ & $10.53 \%$ & $4.19 \%$ & $2.25 \%$ & $0.44 \%$ \\
\hline
\end{tabular}

This table shows the total number of observations and the relative frequencies of ratings at origination and at the beginning of the year. The panel data is based on securitizations rated by CRA Moody's Investors Service. The following observations were excluded: i) transaction observations which can not be placed into the categories asset-backed security, collateralized debt obligation, commercial mortgage-backed security, residential mortgage-backed security or home equity loan security; ii) transaction observations where the monetary volume and therefore relative credit enhancement and thickness of individual tranches could not be determined without setting additional assumptions; iii) transaction observations which are not based on the currency USD or transaction observations which are not originated in the USA; iv) tranche observations which relate to years prior to 1997 due to a limited number of observations, v) tranche observations which have experienced an impairment event in prior years. The number of rated tranches has increased at an increasing rate. The rating quality of rated tranches has generally decreased over time as a smaller fraction of tranches are rated Aaa. 
Table 3

\section{Total number of observations, relative frequencies of asset portfolio and securitization characteristics}

Panel A: Asset portfolio characteristics

\begin{tabular}{c|c|r|r|r|r|r|r|r|r|r|r}
\hline Year & All & \multicolumn{1}{c|}{ ABS } & \multicolumn{1}{c|}{ CDO } & CMBS & HEL & RMBS & Sec. & Re-Sec. & Small & Medium & Big \\
\hline 1997 & 10,957 & $17.03 \%$ & $0.77 \%$ & $2.92 \%$ & $14.88 \%$ & $64.41 \%$ & $93.01 \%$ & $6.99 \%$ & $79.55 \%$ & $15.80 \%$ & $4.65 \%$ \\
1998 & 12,839 & $20.05 \%$ & $1.16 \%$ & $4.15 \%$ & $18.70 \%$ & $55.94 \%$ & $94.34 \%$ & $5.66 \%$ & $75.91 \%$ & $18.40 \%$ & $5.69 \%$ \\
1999 & 13,855 & $22.29 \%$ & $2.36 \%$ & $6.05 \%$ & $21.52 \%$ & $47.78 \%$ & $95.51 \%$ & $4.49 \%$ & $72.39 \%$ & $20.27 \%$ & $7.34 \%$ \\
2000 & 14,941 & $23.97 \%$ & $4.69 \%$ & $8.28 \%$ & $22.07 \%$ & $40.99 \%$ & $96.31 \%$ & $3.69 \%$ & $69.47 \%$ & $22.46 \%$ & $8.07 \%$ \\
2001 & 16,309 & $24.29 \%$ & $6.97 \%$ & $9.60 \%$ & $21.94 \%$ & $37.19 \%$ & $96.87 \%$ & $3.13 \%$ & $68.61 \%$ & $22.92 \%$ & $8.47 \%$ \\
2002 & 18,814 & $21.95 \%$ & $8.77 \%$ & $11.43 \%$ & $20.75 \%$ & $37.11 \%$ & $97.47 \%$ & $2.53 \%$ & $64.87 \%$ & $25.76 \%$ & $9.37 \%$ \\
2003 & 21,416 & $19.91 \%$ & $9.96 \%$ & $12.49 \%$ & $20.83 \%$ & $36.81 \%$ & $97.87 \%$ & $2.13 \%$ & $61.16 \%$ & $28.52 \%$ & $10.32 \%$ \\
2004 & 22,728 & $18.73 \%$ & $11.83 \%$ & $13.24 \%$ & $24.17 \%$ & $32.03 \%$ & $97.95 \%$ & $2.05 \%$ & $55.39 \%$ & $31.34 \%$ & $13.27 \%$ \\
2005 & 28,302 & $14.17 \%$ & $12.14 \%$ & $13.20 \%$ & $28.26 \%$ & $32.23 \%$ & $98.32 \%$ & $1.68 \%$ & $49.68 \%$ & $33.31 \%$ & $17.02 \%$ \\
2006 & 41,247 & $9.53 \%$ & $11.00 \%$ & $11.35 \%$ & $30.42 \%$ & $37.69 \%$ & $98.85 \%$ & $1.15 \%$ & $43.58 \%$ & $35.66 \%$ & $20.76 \%$ \\
2007 & 57,661 & $6.75 \%$ & $11.40 \%$ & $10.38 \%$ & $31.80 \%$ & $39.67 \%$ & $98.97 \%$ & $1.03 \%$ & $39.99 \%$ & $37.45 \%$ & $22.56 \%$ \\
2008 & 66,374 & $6.11 \%$ & $12.10 \%$ & $10.70 \%$ & $29.76 \%$ & $41.33 \%$ & $98.85 \%$ & $1.15 \%$ & $39.65 \%$ & $37.29 \%$ & $23.07 \%$ \\
\hline Total & 325,443 & $17.06 \%$ & $7.76 \%$ & $9.48 \%$ & $23.76 \%$ & $41.93 \%$ & $97.03 \%$ & $2.97 \%$ & $60.02 \%$ & $27.43 \%$ & $12.55 \%$ \\
\hline
\end{tabular}

Panel B: Securitization characteristics

\begin{tabular}{r|r|r|r|r|r|r|r|r|r|r}
\hline Year & All & Junior & Mezzanine & Senior & Thin & Thick & $\begin{array}{r}\text { OY } \leq \\
\mathbf{2 0 0 4}\end{array}$ & OY2005 & OY2006 & OY2007 \\
\hline 1997 & 10,957 & $30.51 \%$ & $38.49 \%$ & $31.00 \%$ & $35.43 \%$ & $64.57 \%$ & $100.00 \%$ & $0.00 \%$ & $0.00 \%$ & $0.00 \%$ \\
1998 & 12,839 & $28.23 \%$ & $39.82 \%$ & $31.95 \%$ & $34.88 \%$ & $65.12 \%$ & $100.00 \%$ & $0.00 \%$ & $0.00 \%$ & $0.00 \%$ \\
1999 & 13,855 & $27.82 \%$ & $42.24 \%$ & $29.94 \%$ & $35.22 \%$ & $64.78 \%$ & $100.00 \%$ & $0.00 \%$ & $0.00 \%$ & $0.00 \%$ \\
2000 & 14,941 & $26.56 \%$ & $44.85 \%$ & $28.59 \%$ & $36.51 \%$ & $63.49 \%$ & $100.00 \%$ & $0.00 \%$ & $0.00 \%$ & $0.00 \%$ \\
2001 & 16,309 & $25.19 \%$ & $47.05 \%$ & $27.76 \%$ & $38.18 \%$ & $61.82 \%$ & $100.00 \%$ & $0.00 \%$ & $0.00 \%$ & $0.00 \%$ \\
2002 & 18,814 & $24.26 \%$ & $48.86 \%$ & $26.87 \%$ & $42.18 \%$ & $57.82 \%$ & $100.00 \%$ & $0.00 \%$ & $0.00 \%$ & $0.00 \%$ \\
2003 & 21,416 & $24.47 \%$ & $49.61 \%$ & $25.92 \%$ & $45.60 \%$ & $54.40 \%$ & $100.00 \%$ & $0.00 \%$ & $0.00 \%$ & $0.00 \%$ \\
2004 & 22,728 & $24.98 \%$ & $49.50 \%$ & $25.52 \%$ & $46.44 \%$ & $53.56 \%$ & $100.00 \%$ & $0.00 \%$ & $0.00 \%$ & $0.00 \%$ \\
2005 & 28,302 & $24.24 \%$ & $50.58 \%$ & $25.19 \%$ & $51.09 \%$ & $48.91 \%$ & $100.00 \%$ & $0.00 \%$ & $0.00 \%$ & $0.00 \%$ \\
2006 & 41,247 & $22.10 \%$ & $51.01 \%$ & $26.89 \%$ & $57.52 \%$ & $42.48 \%$ & $59.76 \%$ & $40.24 \%$ & $0.00 \%$ & $0.00 \%$ \\
2007 & 57,661 & $22.47 \%$ & $51.28 \%$ & $26.25 \%$ & $61.73 \%$ & $38.27 \%$ & $37.35 \%$ & $28.09 \%$ & $34.56 \%$ & $0.00 \%$ \\
2008 & 66,374 & $21.28 \%$ & $52.27 \%$ & $26.44 \%$ & $62.16 \%$ & $37.84 \%$ & $29.14 \%$ & $23.29 \%$ & $28.04 \%$ & $19.52 \%$ \\
\hline Total & 325,443 & $25.18 \%$ & $47.13 \%$ & $27.69 \%$ & $45.58 \%$ & $54.42 \%$ & $85.52 \%$ & $7.64 \%$ & $5.22 \%$ & $1.63 \%$ \\
\hline
\end{tabular}

This table shows the total number of observations and the relative frequencies of asset portfolio and securitization characteristics. Asset portfolio characteristics are the asset portfolio category, the resecuritization status and the asset portfolio size. The asset portfolio categories are asset backed security (ABS), collateralized debt obligation (CDO), commercial mortgage-backed security (CMBS), home equity loan security (HEL) and residential mortgage-backed security (RMBS). The resecuritization status indicates whether a transaction is a resecuritization of previous transactions or a primary securitization. The asset portfolio size is categorized into Small (inflation-adjusted asset portfolio size less than or equal to $\$ 500$ million), Medium (asset portfolio size greater than $\$ 500$ million and less than or equal to $\$ 1,000$ million) and Big (asset portfolio size greater than $\$ 1,000$ million). The number of rated tranches has increased at an increasing rate. The relative frequency of $C D O$ and HEL has increased. The relative frequency of resecuritizations has generally decreased. The asset portfolio size has increased.

Securitization characteristics are the subordination level, the thickness and the origination year. The subordination level Junior indicates that a tranche attaches between 0 and $5 \%$, Mezzanine indicates that a tranche attaches between 5\% and 30\% and Senior indicates that a tranche attaches between 30\% and 100\%. The relative frequency of mezzanine and thin tranches has increased. 
Table 2 shows the relative frequency of rating categories at origination (Panel $A$ ) and at the beginning of the observation year (Panel $B$ ). In both panels, the average rating quality deteriorates over time as the relative frequency of the rating category Aaa declined. This may reflect i) a deterioration of the average asset portfolio quality, ii) a higher average risk level induced by the securitization structure (eg subordination, thickness or features such as embedded options, which are not addressed in this paper) or iii) a change of the CRA rating methodology.

Table 3 shows the relative frequency of asset portfolio (Panel A) and securitization characteristics (Panel B). Asset portfolio characteristics are the asset portfolio category, the resecuritization status and the asset portfolio size. The asset portfolio categories are assetbacked security (ABS), collateralized debt obligation (CDO), commercial mortgage-backed security (CMBS), home equity loan security (HEL) and residential mortgage-backed security (RMBS). The asset portfolio size is categorized into Small (asset portfolio size less than or equal to $\$ 500$ million), Medium (asset portfolio size greater than $\$ 500$ million and less than or equal to $\$ 1,000$ million) and Big (asset portfolio size greater than $\$ 1,000$ million).

The number of rated tranches has increased at an increasing rate. The relative frequency of CDO and HEL has increased. The relative frequency of resecuritizations has generally decreased. The inflation-adjusted asset portfolio size has increased.

Securitization characteristics are the subordination level, thickness and origination year. The subordination level Junior indicates that a tranche attaches between $0 \%$ and $5 \%$, Mezzanine indicates that a tranche attaches between $5 \%$ and $30 \%$ and Senior indicates that a tranche attaches between $30 \%$ and 100\%.

The relative frequency of mezzanine and thin tranches has increased while the relative frequency of the various origination years (OY) depends on the origination as well as the maturity and impairment of securitizations.

Generally speaking, the validation of credit ratings is complicated as the use of ratings involves two steps: firstly the ordinal assessments of the financial risk of issuers or issues by CRAs and secondly the calibration of these ordinal ratings to metric credit risk measures such as default rates, loss rates given default or unconditional loss rates. This calibration step is generally opaque and investors rely on impairment rate tables which are periodically published by CRAs. These tables aggregate the impairment events over dimensions such as rating class or observation year. The data set enables the estimation of impairment risk based on the most detailed information level, ie the individual transaction in a given observation year. Table 4 and Table 5 show the impairment rates over time for all tranches as well as per rating category, asset portfolio and securitization characteristics.

US securitizations have experienced two economic downturns during the observation period: the first one in 2002 subsequent to the US terrorist attacks (a period characterized by large bankruptcies such as Enron, WorldCom and various US airlines) and the Global Financial Crisis. With regard to the GFC, the impairment rate has increased by a factor of approximately 80 within two years between 2006 and 2008. Approximately $81 \%$ of all impairment events relate to $2008 .^{18}$

18 While this number underlines the severity of the GFC and the importance of this study it raises the concern of imbalances in the data set. We address this issue for robustness by i) controlling for rating years, ii) analyzing the data for the period prior to the GFC and the GFC and iii) focusing on relative differences within these controlled environments. 
Table 4

\section{Impairment rates for all observations, per rating at origination and at the beginning of the year}

Panel A: Rating at origination

\begin{tabular}{l|c|c|c|c|c|c}
\hline \multicolumn{1}{c|}{ Year } & All & Aaa-A & Baa & Ba & B & \multicolumn{1}{c}{ Caa } \\
\hline 1997 & $0.27 \%$ & $0.00 \%$ & $2.17 \%$ & $4.62 \%$ & $11.36 \%$ & $0.00 \%$ \\
1998 & $0.19 \%$ & $0.03 \%$ & $1.83 \%$ & $1.74 \%$ & $2.40 \%$ & $0.00 \%$ \\
1999 & $0.35 \%$ & $0.15 \%$ & $1.88 \%$ & $2.40 \%$ & $1.08 \%$ & $0.00 \%$ \\
2000 & $0.31 \%$ & $0.08 \%$ & $0.95 \%$ & $3.79 \%$ & $2.55 \%$ & $0.00 \%$ \\
2001 & $0.58 \%$ & $0.07 \%$ & $2.47 \%$ & $2.74 \%$ & $8.63 \%$ & $5.88 \%$ \\
2002 & $1.08 \%$ & $0.10 \%$ & $4.77 \%$ & $7.61 \%$ & $7.09 \%$ & $0.00 \%$ \\
2003 & $0.85 \%$ & $0.19 \%$ & $3.88 \%$ & $2.88 \%$ & $3.02 \%$ & $20.83 \%$ \\
2004 & $0.94 \%$ & $0.61 \%$ & $1.55 \%$ & $2.70 \%$ & $3.11 \%$ & $26.92 \%$ \\
2005 & $0.27 \%$ & $0.07 \%$ & $0.95 \%$ & $0.43 \%$ & $1.86 \%$ & $5.00 \%$ \\
2006 & $0.20 \%$ & $0.07 \%$ & $0.41 \%$ & $0.57 \%$ & $2.68 \%$ & $0.00 \%$ \\
2007 & $2.49 \%$ & $0.48 \%$ & $7.37 \%$ & $16.80 \%$ & $1.77 \%$ & $0.00 \%$ \\
2008 & $16.02 \%$ & $9.88 \%$ & $38.05 \%$ & $36.96 \%$ & $28.07 \%$ & $90.63 \%$ \\
\hline Total & $1.96 \%$ & $0.17 \%$ & $2.57 \%$ & $4.21 \%$ & $4.14 \%$ & $5.33 \%$ \\
\hline
\end{tabular}

Panel B: Rating at the beginning of a year

\begin{tabular}{l|c|c|c|r|r|r}
\hline \multicolumn{1}{c|}{ Year } & All & Aaa-A & Baa & Ba & \multicolumn{1}{c|}{ B } & \multicolumn{1}{c}{ Caa } \\
\hline 1997 & $0.27 \%$ & $0.00 \%$ & $0.39 \%$ & $6.64 \%$ & $12.73 \%$ & $0.00 \%$ \\
1998 & $0.19 \%$ & $0.03 \%$ & $1.08 \%$ & $4.42 \%$ & $2.10 \%$ & $0.00 \%$ \\
1999 & $0.35 \%$ & $0.06 \%$ & $1.70 \%$ & $2.84 \%$ & $5.21 \%$ & $21.43 \%$ \\
2000 & $0.31 \%$ & $0.02 \%$ & $0.56 \%$ & $2.96 \%$ & $3.13 \%$ & $35.71 \%$ \\
2001 & $0.58 \%$ & $0.06 \%$ & $2.13 \%$ & $3.57 \%$ & $8.36 \%$ & $12.50 \%$ \\
2002 & $1.08 \%$ & $0.06 \%$ & $2.43 \%$ & $11.72 \%$ & $8.89 \%$ & $26.00 \%$ \\
2003 & $0.85 \%$ & $0.05 \%$ & $2.16 \%$ & $4.96 \%$ & $8.00 \%$ & $23.16 \%$ \\
2004 & $0.94 \%$ & $0.27 \%$ & $1.37 \%$ & $3.07 \%$ & $5.30 \%$ & $28.99 \%$ \\
2005 & $0.27 \%$ & $0.00 \%$ & $0.17 \%$ & $0.79 \%$ & $2.89 \%$ & $13.06 \%$ \\
2006 & $0.20 \%$ & $0.00 \%$ & $0.12 \%$ & $0.50 \%$ & $2.07 \%$ & $17.25 \%$ \\
2007 & $2.49 \%$ & $0.44 \%$ & $7.20 \%$ & $16.49 \%$ & $4.68 \%$ & $16.73 \%$ \\
2008 & $16.02 \%$ & $7.53 \%$ & $34.11 \%$ & $45.93 \%$ & $55.16 \%$ & $77.84 \%$ \\
\hline Total & $1.96 \%$ & $0.09 \%$ & $1.75 \%$ & $5.27 \%$ & $5.76 \%$ & $17.71 \%$ \\
\hline
\end{tabular}

This table shows impairment rates for all observations, per rating at origination and at the beginning of the year. The impairment rate is the ratio between the number of impairment events and the total number of observations in a given category and observation year. Impairment events '[...]fall into one of two categories, principal impairments and interest impairments. Principal impairments include securities that have suffered principal write-downs or principal losses at maturity and securities that have been downgraded to $\mathrm{Ca} / \mathrm{C}$, even if they have not yet experienced an interest shortfall or principal write-down. Interest impairments, or interestimpaired securities, include securities that are not principal impaired and have experienced only interest shortfalls.' (compare Moody's Investors Service (2008)).

Impairment rates are high in 2002 and 2007/2008. Impairment rates increase from rating category Aaa to C and fluctuate over time. The rating categories $\mathrm{Aaa}, \mathrm{Aa}$ and $\mathrm{A}$ are aggregated into one category Aaa-A due to the limited number of impairment events. 
Table 5

\section{Impairment rates for all observations as well as asset portfolio and securitization} characteristics

Panel A: Asset portfolio characteristics

\begin{tabular}{l|c|c|c|r|r|r|r|r|r|c}
\hline Year & All & \multicolumn{1}{|c|}{ ABS } & \multicolumn{1}{c|}{ CDO } & \multicolumn{1}{c|}{ HEL } & \multicolumn{1}{c|}{ MBS } & \multicolumn{1}{c|}{ Sec. } & Re-Sec. & Small & Medium & Big \\
\hline 1997 & 10,957 & $0.00 \%$ & $0.00 \%$ & $1.41 \%$ & $0.09 \%$ & $0.29 \%$ & $0.00 \%$ & $0.34 \%$ & $0.00 \%$ & $0.00 \%$ \\
1998 & 12,839 & $0.16 \%$ & $0.00 \%$ & $0.79 \%$ & $0.03 \%$ & $0.20 \%$ & $0.14 \%$ & $0.26 \%$ & $0.00 \%$ & $0.00 \%$ \\
1999 & 13,855 & $0.36 \%$ & $0.61 \%$ & $0.97 \%$ & $0.08 \%$ & $0.36 \%$ & $0.00 \%$ & $0.47 \%$ & $0.04 \%$ & $0.00 \%$ \\
2000 & 14,941 & $0.42 \%$ & $1.43 \%$ & $0.49 \%$ & $0.07 \%$ & $0.30 \%$ & $0.54 \%$ & $0.41 \%$ & $0.03 \%$ & $0.17 \%$ \\
2001 & 16,309 & $0.73 \%$ & $3.96 \%$ & $0.34 \%$ & $0.12 \%$ & $0.60 \%$ & $0.20 \%$ & $0.71 \%$ & $0.27 \%$ & $0.43 \%$ \\
2002 & 18,814 & $2.15 \%$ & $4.91 \%$ & $0.36 \%$ & $0.22 \%$ & $1.11 \%$ & $0.00 \%$ & $1.36 \%$ & $0.62 \%$ & $0.45 \%$ \\
2003 & 21,416 & $2.18 \%$ & $1.97 \%$ & $0.58 \%$ & $0.21 \%$ & $0.87 \%$ & $0.22 \%$ & $0.94 \%$ & $0.72 \%$ & $0.72 \%$ \\
2004 & 22,728 & $3.27 \%$ & $1.56 \%$ & $0.20 \%$ & $0.20 \%$ & $0.95 \%$ & $0.21 \%$ & $1.28 \%$ & $0.55 \%$ & $0.43 \%$ \\
2005 & 28,302 & $0.45 \%$ & $0.58 \%$ & $0.21 \%$ & $0.17 \%$ & $0.28 \%$ & $0.00 \%$ & $0.37 \%$ & $0.16 \%$ & $0.21 \%$ \\
2006 & 41,247 & $0.69 \%$ & $0.26 \%$ & $0.16 \%$ & $0.11 \%$ & $0.20 \%$ & $0.00 \%$ & $0.25 \%$ & $0.21 \%$ & $0.07 \%$ \\
2007 & 57,661 & $0.46 \%$ & $4.67 \%$ & $5.53 \%$ & $0.33 \%$ & $2.51 \%$ & $0.17 \%$ & $2.74 \%$ & $2.44 \%$ & $2.12 \%$ \\
2008 & 66,374 & $0.17 \%$ & $24.93 \%$ & $29.00 \%$ & $8.39 \%$ & $15.98 \%$ & $19.40 \%$ & $13.50 \%$ & $18.65 \%$ & $16.11 \%$ \\
\hline Total & 325,443 & $0.92 \%$ & $3.74 \%$ & $3.34 \%$ & $0.83 \%$ & $1.97 \%$ & $1.74 \%$ & $1.89 \%$ & $1.97 \%$ & $1.73 \%$ \\
\hline
\end{tabular}

Panel B: Securitization characteristics

\begin{tabular}{l|c|r|c|r|r|r|r|r|l|l}
\hline Year & All & Junior & Mezzanine & Senior & Thin & Thick & $\begin{array}{r}\text { OY } \leq \\
\mathbf{2 0 0 4}\end{array}$ & OY2005 & OY2006 & OY2007 \\
\hline 1997 & 10,957 & $0.90 \%$ & $0.00 \%$ & $0.00 \%$ & $0.46 \%$ & $0.17 \%$ & $0.27 \%$ & & & \\
1998 & 12,839 & $0.52 \%$ & $0.12 \%$ & $0.00 \%$ & $0.33 \%$ & $0.12 \%$ & $0.19 \%$ & & & \\
1999 & 13,855 & $0.73 \%$ & $0.32 \%$ & $0.02 \%$ & $0.41 \%$ & $0.31 \%$ & $0.35 \%$ & & & \\
2000 & 14,941 & $0.96 \%$ & $0.12 \%$ & $0.00 \%$ & $0.33 \%$ & $0.30 \%$ & $0.31 \%$ & & & \\
2001 & 16,309 & $1.53 \%$ & $0.42 \%$ & $0.00 \%$ & $0.75 \%$ & $0.48 \%$ & $0.58 \%$ & & & \\
2002 & 18,814 & $3.40 \%$ & $0.50 \%$ & $0.06 \%$ & $1.68 \%$ & $0.65 \%$ & $1.08 \%$ & & & \\
2003 & 21,416 & $1.95 \%$ & $0.75 \%$ & $0.02 \%$ & $1.23 \%$ & $0.54 \%$ & $0.85 \%$ & & & \\
2004 & 22,728 & $1.60 \%$ & $0.97 \%$ & $0.22 \%$ & $1.14 \%$ & $0.76 \%$ & $0.94 \%$ & & & \\
2005 & 28,302 & $0.73 \%$ & $0.18 \%$ & $0.01 \%$ & $0.41 \%$ & $0.12 \%$ & $0.27 \%$ & & & \\
2006 & 41,247 & $0.61 \%$ & $0.11 \%$ & $0.02 \%$ & $0.21 \%$ & $0.18 \%$ & $0.32 \%$ & $0.01 \%$ & & \\
2007 & 57,661 & $8.56 \%$ & $1.09 \%$ & $0.03 \%$ & $3.80 \%$ & $0.37 \%$ & $0.83 \%$ & $0.62 \%$ & $5.79 \%$ & \\
2008 & 66,374 & $40.08 \%$ & $13.55 \%$ & $1.54 \%$ & $22.97 \%$ & $4.62 \%$ & $2.92 \%$ & $11.55 \%$ & $26.50 \%$ & $25.88 \%$ \\
\hline Total & 325,443 & $5.13 \%$ & $1.51 \%$ & $0.16 \%$ & $2.81 \%$ & $0.72 \%$ & $0.74 \%$ & $4.06 \%$ & $16.14 \%$ & $25.88 \%$ \\
\hline
\end{tabular}

This table shows the impairment rates for all observations, per deal and tranche characteristics. Impairment rates are high in 2002 and 2007/2008. Impairment rates per rating category fluctuate over time. Impairment rates per asset portfolio type increase in 2002 for CDOs and in 2008 especially for CDOs, HELs and MBSs. The asset classes CMBS and RMBS are aggregated to the category MBS due to the limited number of impairment events. The impairment rate has particularly increased in 2008 especially for resecuritizations, all subordination levels and tranches originated in years prior to the GFC. 
Table 4 shows the impairment rates for rating categories at origination (Panel $A$ ) and at the beginning of the observation year (Panel $B$ ). In both panels, the impairment rate increases for lower rating categories (ie from Aaa-A to $\mathrm{Caa}$ ) and fluctuates over time with a dramatic increase during the GFC for all rating classes. The relative increase decreases during the GFC with the rating quality (ie from Caa to Aaa-A). Ironically, investors were most surprised by the increase of impairment rates of highly rated securitizations. ${ }^{19}$

Table 5 shows the impairment rates for asset portfolio (Panel A) and securitization characteristics (Panel B). Impairment rates are high in 2002 and 2007/2008. Impairment rates per rating category fluctuate over time. Impairment rates per asset portfolio type increased in 2002 for CDOs and in 2008 especially for CDOs, MBSs and HELs. HELs include sub-prime mortgage loans and the impairment risk increased to a larger degree than the one of MBSs. It can also be seen that HELs and MBSs did not experience an economic downturn in 2002. The asset classes CMBS and RMBS are aggregated to the category MBS due to the limited number of impairment events. The impairment rate has increased in 2008 especially for resecuritizations. The levels of the impairment rates are fundamentally different between the various asset portfolio categories. Impairment rates of junior tranches increased more than impairment rates of senior tranches. Impairment rates of thin tranches increased more than impairment rates of thick tranches and the ones of more recent vintage (with regard to the GFC) more so than the ones of older vintage.

\subsection{H1 - Impairment risk hypotheses}

Table 6 presents two probit models linking the impairment events with CRA ratings. Model 1 takes the dummy-coded ratings (reference category: Aaa-A) into account. Model 1 shows that CRA ratings explain the credit risk. As measures for in-sample accuracy of the models the Pseudo- $R^{2}$, re-scaled $R^{2}$, and the area under the receiver operating characteristic curve (AUROC) are calculated (see Agresti (1984)). ${ }^{20}$ The parameter estimates increase from rating Aaa-A to rating $\mathrm{Caa}$ and are significant. This demonstrates that the ratings imply higher impairment risk from Aaa to Caa and that ratings explain impairment risk.

Model 2 includes the ratings as well as the dummy-coded rating years (reference category: 1997). The rating years are significant which implies that the realized impairment rates differ between the years. This has been pointed out by previous studies on corporate ratings (compare eg Loeffler (2004) which conclude that ratings average the risk over the business cycle. ${ }^{21}$ In other words, Model 2 shows that CRA ratings do not explain the increased level of impairment risk especially during economic downturns. We include rating year dummies in all subsequent models to control for this and further analyze the prediction quality of ratings in hypothesis $\mathrm{H} 3$.

19 Please note that inconsistencies may reflect the accuracy as well as the stochastic nature of impairment events. The latter is particularly relevant if the number of observations is low for a given category. One example is the impairment rates for the rating classes $\mathrm{Ba}(16.49 \%)$ and $\mathrm{B}(4.68 \%)$ in 2007 in Panel B of Table 4. These inconsistencies are in line with reports by the data-providing CRA (compare Moody's Investors Service (2008)).

20 All measures are bounded between zero (lowest fit) and one (highest fit).

21 Such models are also known as through-the-cycle models. 
Table 6

The link between impairment risk, CRA ratings and time

\begin{tabular}{|c|c|c|}
\hline Variable & Model 1 & Model 2 \\
\hline Intercept & $\begin{array}{l}-2.1517^{\star * *} \\
0.0062\end{array}$ & $\begin{array}{l}-3.2346^{\star \star *} \\
0.0741\end{array}$ \\
\hline Baa & $\begin{array}{l}0.8351^{\star \star \star} \\
0.0107\end{array}$ & $\begin{array}{l}1.0397^{\star * *} \\
0.0133\end{array}$ \\
\hline $\mathrm{Ba}$ & $\begin{array}{l}1.1900^{\star \star \star} \\
0.0133\end{array}$ & $\begin{array}{l}1.4301^{\star \star \star} \\
0.0163\end{array}$ \\
\hline$B$ & $\begin{array}{l}1.3276^{\star \star \star} \\
0.0167\end{array}$ & $\begin{array}{l}1.5209^{\star \star *} \\
0.0202\end{array}$ \\
\hline Caa & $\begin{array}{l}2.0038^{\star \star \star} \\
0.0287\end{array}$ & $\begin{array}{l}2.2803^{\star \star \star} \\
0.0344\end{array}$ \\
\hline 1998 & & $\begin{array}{r}-0.1159 \\
0.1051\end{array}$ \\
\hline 1999 & & $\begin{array}{l}0.0142 \\
0.0933\end{array}$ \\
\hline 2000 & & $\begin{array}{r}-0.1526 \\
0.0955\end{array}$ \\
\hline 2001 & & $\begin{array}{l}0.1083 \\
0.0855\end{array}$ \\
\hline 2002 & & $\begin{array}{l}0.3217^{\star \star \star} \\
0.0804\end{array}$ \\
\hline 2003 & & $\begin{array}{l}0.1596^{\star *} \\
0.0807\end{array}$ \\
\hline 2004 & & $\begin{array}{l}0.1622^{\star \star} \\
0.0796\end{array}$ \\
\hline 2005 & & $\begin{array}{l}-0.4408^{\star \star \star} \\
0.087\end{array}$ \\
\hline 2006 & & $\begin{array}{l}-0.5317^{\star \star \star} \\
0.0859\end{array}$ \\
\hline 2007 & & $\begin{array}{l}0.6662^{\star \star \star} \\
0.0749\end{array}$ \\
\hline 2008 & & $\begin{array}{l}1.7862^{\star \star \star} \\
0.0741\end{array}$ \\
\hline Pseudo R-square & 0.0520 & 0.1220 \\
\hline R-square rescaled & 0.1818 & 0.4265 \\
\hline AUROC & 0.7688 & 0.9231 \\
\hline
\end{tabular}

This table shows parameter estimates for the probit models Model 1 to Model 2. The model specification is $P\left(D_{i j t}=1\right)=\Phi\left(\beta^{\prime} \chi_{i j t}\right)$. Standard errors are in parentheses. The significance is indicated as follows: ***: significant at $1 \%, * *$ : significant at $5 \%, *$ : significant at $10 \%$. AUROC is the area under the receiver operating characteristic curve (see Agresti (1984)).

Model 1 shows that CRA ratings explain the credit risk over time. Model 2 shows that CRA ratings are unable to explain changes in the increased level of impairment risk over time. 


\section{Table 7}

The link between impairment risk, CRA ratings, asset portfolio and securitization characteristics, with rating year dummies

\begin{tabular}{|c|c|c|c|c|c|}
\hline Variable & Model 3 & Model 4 & Model 5 & $\begin{array}{c}\text { Model } 6 \\
\text { (prior GFC) }\end{array}$ & $\begin{array}{c}\text { Model } 7 \\
\text { (GFC) }\end{array}$ \\
\hline \multirow[t]{2}{*}{ Intercept } & $-5.6417^{\star \star \star}$ & $-2.8000^{\star \star \star}$ & $-4.5874^{\star \star \star}$ & $0.2176^{\star * *}$ & $-7.0547^{\star \star \star}$ \\
\hline & 0.1575 & 0.0750 & 0.1694 & 0.3047 & 0.2006 \\
\hline \multirow[t]{2}{*}{ Baa } & $0.9849 * \star \star$ & $0.6949 * \star \star$ & $0.5668^{\star \star \star}$ & $0.8263^{\star \star *}$ & $0.5472^{\star \star \star}$ \\
\hline & 0.0138 & 0.0143 & 0.0152 & 0.0481 & 0.0169 \\
\hline \multirow[t]{2}{*}{$\mathrm{Ba}$} & $1.4267^{\star \star \star}$ & $1.0748^{\star \star \star}$ & $0.9934^{\star * \star}$ & $1.4125^{\star \star \star}$ & $0.9244^{\star \star *}$ \\
\hline & 0.0170 & 0.0172 & 0.0183 & 0.0510 & 0.0208 \\
\hline \multirow[t]{2}{*}{ B } & $1.6326^{\star \star \star}$ & $1.1510^{\star \star \star}$ & $1.2224^{\star \star \star}$ & $1.8561^{\star \star \star}$ & $1.0900 * \star \star$ \\
\hline & 0.0216 & 0.0212 & 0.0228 & 0.0558 & 0.0268 \\
\hline \multirow[t]{2}{*}{ Caa } & $2.3478^{\star \star *}$ & $1.9833^{\star \star \star}$ & $1.9779 * \star \star$ & $2.5822^{\star \star \star}$ & $1.7801^{\star * *}$ \\
\hline & 0.0365 & 0.0356 & 0.0382 & 0.0665 & 0.0495 \\
\hline \multirow[t]{2}{*}{ CDO } & $0.5059^{\star \star \star}$ & & $0.5925^{\star \star \star}$ & $-0.3066^{\star \star \star}$ & $2.1625^{\star \star \star}$ \\
\hline & 0.0263 & & 0.0274 & 0.0428 & 0.0801 \\
\hline \multirow[t]{2}{*}{ HEL } & $0.5885^{\star \star \star}$ & & $0.4660^{\star \star \star}$ & $-0.4728^{\star \star \star}$ & $1.9970^{\star \star \star *}$ \\
\hline & 0.0245 & & 0.0252 & 0.0419 & 0.0789 \\
\hline \multirow[t]{2}{*}{ MBS } & $-0.2606^{\star \star \star}$ & & $-0.4380^{\star \star \star}$ & $-1.1824^{\star \star \star}$ & $1.0394^{\star \star \star}$ \\
\hline & 0.0253 & & 0.0262 & 0.0475 & 0.0791 \\
\hline \multirow[t]{2}{*}{ Resecuritisation } & $0.2355^{\star \star \star}$ & & $0.3450 * \star \star$ & -0.0909 & $0.3954 * \star \star$ \\
\hline & 0.0528 & & 0.0561 & 0.1530 & 0.0634 \\
\hline \multirow[t]{2}{*}{ Deal size } & $0.1220^{\star \star \star}$ & & $0.0994^{\star \star \star}$ & $-0.1383^{\star \star \star}$ & $0.1657^{\star \star \star}$ \\
\hline & 0.0071 & & 0.0077 & 0.0151 & 0.0090 \\
\hline \multirow[t]{2}{*}{ Subordination } & & $-2.6234^{\star \star \star}$ & $-3.4892^{\star \star \star}$ & $-1.4095^{\star \star \star}$ & $-4.0653^{\star \star \star}$ \\
\hline & & 0.0602 & 0.0792 & 0.1708 & 0.0935 \\
\hline \multirow[t]{2}{*}{ Thickness } & & $-0.5138^{\star \star \star}$ & $-0.6260^{\star \star \star}$ & $-0.5851^{\star \star \star}$ & $-0.5317^{\star \star \star}$ \\
\hline & & 0.0388 & 0.0454 & 0.0893 & 0.0538 \\
\hline Year Dummies & Yes & Yes & Yes & Yes & Yes \\
\hline Pseudo R-square & 0.1355 & 0.1328 & 0.1476 & 0.0246 & 0.2231 \\
\hline R-square rescaled & 0.4735 & 0.4643 & 0.5159 & 0.4048 & 0.4729 \\
\hline AUROC & 0.9427 & 0.9416 & 0.9540 & 0.9507 & 0.9171 \\
\hline
\end{tabular}

This table shows parameter estimates for the probit model Model 3 to Model 7. The model specification is $P\left(D_{i j t}=1\right)=\Phi\left(\beta^{\prime} \chi_{i j t}\right)$. Standard errors are in parentheses. The significance is indicated as follows: ***: significant at $1 \%$, **: significant at $5 \%$, *: significant at $10 \%$. AUROC is the area under the receiver operating characteristic curve (see Agresti (1984)).

The inclusion of asset portfolio (Model 3 and 5) and securitization (Model 4 and 5) characteristics after controlling for credit rating and rating year explains impairment risk. The ramifications are that CRA ratings do not sufficiently account for the impairment risk stipulated by asset portfolio and securitization characteristics for given rating years. The division of the data into pre-GFC and GFC years shows that the asset portfolio characteristics (asset portfolio category, resecuritization status and deal size) are cyclical as the parameter sign changes while the securitization characteristics are not cyclical. CRAs are unable to measure both relationships.

Table 7 confirms that the inclusion of asset portfolio (Model 3 and 5, Model 6 and 7) and securitization (Model 4 and 5, Model 6 and 7) characteristics after controlling for credit 
ratings add to the explanation of impairment risk. The ramifications are that CRA ratings do not sufficiently account for the average impairment risk stipulated by asset portfolio and securitization characteristics over time.

The split of the data into pre-GFC and GFC years shows that the asset portfolio characteristics (asset portfolio category, resecuritization status and deal size) are cyclical as the parameter sign changes while the securitization characteristics are not cyclical. Impairment risk is significantly lower (higher) for CDO, HEL, MBS, resecuritization and big deals before (during) the GFC than during (before) the GFC. Likewise, subordination and tranche thickness are negatively related to impairment risk and ratings are not able to explain this.

In summary, we reject the hypothesis $\mathrm{H} 1 \mathrm{a}$ that ratings contain all information about the average asset quality of the asset portfolio relevant for impairment risk. In addition, we reject hypothesis $\mathrm{H} 1 \mathrm{~b}$ that ratings contain all information about the characteristics of securitizations relevant for impairment risk. CRAs do not take into account all the available asset portfolio and securitization information that is relevant to explaining impairment risk. The important ramifications are that i) CRAs may have to include such characteristics into the rating models or ii) users such as investors or prudential regulators should apply asset portfolio specific impairment rates to ratings when interpreting CRA ratings. ${ }^{22}$

\subsection{H2 - Agency incentive hypotheses}

Commercial CRAs may have a monetary incentive to bias the measures of impairment risk. The analyzed incentive hypotheses relate to the origination process during which a CRA may underestimate the risk in general (as fee revenue is high at origination) or during economic booms (as origination volumes and therefore fee revenue is high during economic booms). ${ }^{23}$

Model 8 in Table 8 shows that different origination years (also known as vintages) differ in risk. Models 9 and $10^{24}$ show that ratings are unable to explain the risk of the different vintages.

Even more interestingly, Models 11 and 12 show that the vintage risk differs between the years prior to the GFC and during the GFC. During the GFC, the risk which is not reflected in ratings, increases for more recent origination and is highest for securitizations, which were originated immediately before the GFC. Vice versa, during years before the GFC, the risk which is not reflected in ratings decreases for more recent originations.

22 Despite the common use of ratings as metric risk measures, CRAs often claim to assess the relative risk, which essentially implies that a rating of a higher alphabetic order involves a lower level of financial risk. In an extension, all models were estimated controlling for the annual average impairment rate to ascertain that the findings relate to the absolute (calibration) as well as relative (discrimination) level of risk. The results are comparable to the ones reported in Tables 6 and 7 .

23 In addition, Bolton et al (2009) argue that investors are naive and reputational risk is low.

24 Model 10 controls for the rating year. Please note that the panel data set looks at origination and monitoring years, ie years between origination and maturity of securitizations. 
Table 8

The link between impairment risk, CRA ratings and incentive characteristic

\begin{tabular}{|c|c|c|c|c|c|}
\hline Variable & Model 8 & Model 9 & Model 10 & $\begin{array}{c}\text { Model 11 } \\
\text { (prior GFC) }\end{array}$ & $\begin{array}{l}\text { Model } 12 \\
\text { (GFC) }\end{array}$ \\
\hline \multirow[t]{2}{*}{ Intercept } & $-2.6520^{\star \star \star}$ & $-3.2727^{\star \star \star}$ & $-3.3453^{\star \star \star}$ & $-3.2831^{\star \star \star}$ & $-4.7431^{\star \star \star}$ \\
\hline & 0.0193 & 0.0264 & 0.0770 & 0.0789 & 0.1628 \\
\hline \multirow[t]{2}{*}{ Baa } & & $1.0302^{\star \star \star}$ & $1.1717^{\star \star \star}$ & $1.0443^{\star \star \star}$ & $1.1979 * \star \star *$ \\
\hline & & 0.0134 & 0.0146 & 0.0423 & 0.0157 \\
\hline \multirow[t]{2}{*}{$\mathrm{Ba}$} & & $1.4544^{\star * *}$ & $1.5794^{\star \star \star}$ & $1.5101^{* \star *}$ & 1.5950 *** \\
\hline & & 0.0164 & 0.0178 & 0.0433 & 0.0201 \\
\hline \multirow[t]{2}{*}{ B } & & $1.7405^{\star \star \star}$ & $1.7628^{\star \star \star}$ & $1.6905^{\star \star \star}$ & $1.7774^{\star \star \star}$ \\
\hline & & 0.0208 & 0.0224 & 0.0464 & 0.0270 \\
\hline \multirow[t]{2}{*}{ Caa } & & $2.5912^{\star \star \star}$ & $2.7181^{\star \star \star}$ & $2.4704^{\star \star \star}$ & $2.9414^{\star \star *}$ \\
\hline & & 0.0344 & 0.0394 & 0.0616 & 0.0604 \\
\hline \multirow[t]{2}{*}{ OY1998 } & $0.3606^{\star \star \star}$ & $0.1266^{\star \star *}$ & $0.1171^{\star \star}$ & $0.1030^{* *}$ & $0.5618^{\star * *}$ \\
\hline & 0.0350 & 0.0446 & 0.0477 & 0.0486 & 0.2010 \\
\hline \multirow[t]{2}{*}{ OY1999 } & 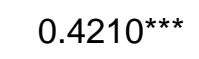 & $0.1307^{\star \star \star}$ & $0.1160^{\star * \star}$ & $0.1294^{\star \star *}$ & $0.1775^{\star \star *}$ \\
\hline & 0.0335 & 0.0423 & 0.0469 & 0.0473 & 0.2043 \\
\hline \multirow[t]{2}{*}{ OY2000 } & $0.4817^{\star \star \star}$ & $0.1095^{\star \star}$ & 0.0866 & 0.0745 & $0.3565^{\star \star \star}$ \\
\hline & 0.0339 & 0.0426 & 0.0474 & 0.0486 & 0.1893 \\
\hline \multirow[t]{2}{*}{ OY2001 } & $0.3010^{\star \star \star}$ & -0.0353 & $-0.0878^{\star \star \star}$ & $-0.1836^{\star \star \star}$ & $0.7052^{\star \star \star}$ \\
\hline & 0.0341 & 0.0428 & 0.0488 & 0.0526 & 0.1750 \\
\hline \multirow[t]{2}{*}{ OY2002 } & $0.2784^{\star \star \star}$ & 0.0618 & $0.0282^{\star \star \star}$ & $-0.2806^{\star \star \star}$ & $1.1220^{\star \star \star}$ \\
\hline & 0.0324 & 0.0400 & 0.0490 & 0.0596 & 0.1679 \\
\hline \multirow[t]{2}{*}{ OY2003 } & $0.1400^{\star \star \star}$ & 0.0613 & $-0.0233^{\star * *}$ & $-0.8856^{\star \star \star}$ & $1.1371^{\star \star \star}$ \\
\hline & 0.0329 & 0.0404 & 0.0521 & 0.1153 & 0.1660 \\
\hline \multirow[t]{2}{*}{ OY2004 } & $0.2993^{\star \star \star}$ & $0.2212^{\star \star \star}$ & $0.1029 * \star \star$ & $-0.8876^{\star \star \star}$ & $1.1386^{\star \star \star}$ \\
\hline & 0.0281 & 0.0346 & 0.0497 & 0.1611 & 0.1640 \\
\hline \multirow[t]{2}{*}{ OY2005 } & $0.8911^{\star \star \star}$ & $1.0017^{\star \star \star}$ & $0.8465^{\star \star \star}$ & $-1.0269 * \star \star$ & $1.8801^{\star * *}$ \\
\hline & 0.0219 & 0.0279 & 0.0445 & 0.2151 & 0.1623 \\
\hline \multirow[t]{2}{*}{ OY2006 } & 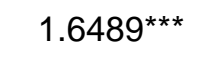 & 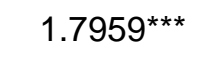 & $1.5317^{\star \star \star}$ & & $2.5416^{\star \star \star}$ \\
\hline & 0.0207 & 0.0267 & 0.0435 & & 0.1620 \\
\hline \multirow[t]{2}{*}{ OY2007 } & $2.0051^{\star \star \star}$ & $2.2405^{\star \star \star}$ & $1.5700^{\star \star \star}$ & & $2.5816^{\star \star \star}$ \\
\hline & 0.0226 & 0.0286 & 0.0447 & & 0.1623 \\
\hline Year Dummies & No & No & Yes & Yes & Yes \\
\hline Pseudo R-square & 0.0744 & 0.1246 & 0.1440 & 0.0205 & 0.2094 \\
\hline R-square rescaled & 0.2602 & 0.4356 & 0.5035 & 0.3377 & 0.4439 \\
\hline AUROC & 0.8533 & 0.9266 & 0.9479 & 0.9285 & 0.8995 \\
\hline
\end{tabular}

This table shows parameter estimates for the probit model Model 8 to Model 12 . The model specification is $P\left(D_{i j t}=1\right)=\Phi\left(\beta^{\prime} \chi_{i j t}\right)$. Standard errors are in parentheses. The significance is indicated as follows: ***: significant at $1 \%$, **: significant at $5 \%$, *: significant at $10 \%$. AUROC is the area under the receiver operating characteristic curve (see Agresti (1984)).

The risk of securitization differs for each origination year (OY) and CRAs are unable to measure this element. In addition, Model 11 and Model 12 show that the risk of recent origination years is high for the GFC and low for years prior to the GFC. 
In order to test the hypotheses $\mathrm{H} 2 \mathrm{a}$ and $\mathrm{H} 2 \mathrm{~b}$, we replace the origination year dummies by the time since origination (TSO) and the securitization volume at origination (SVO). TSO is equal to one in the origination year and greater than one in monitoring years. ${ }^{25}$

Table 9

The link between impairment risk,CRA ratings and incentive characteristics (cont.)

\begin{tabular}{|c|c|c|c|c|c|c|c|c|c|}
\hline \multirow[b]{2}{*}{ Variable } & \multicolumn{3}{|c|}{ All years } & \multicolumn{3}{|c|}{ prior GFC } & \multicolumn{3}{|c|}{ GFC } \\
\hline & Model 13 & Model 14 & Model 15 & Model 16 & Model 17 & Model 18 & Model 19 & Model 20 & Model 21 \\
\hline \multirow[t]{2}{*}{ Intercept } & $-2.6666^{\star \star \star}$ & $-20.5275^{\star \star \star}$ & $-14.5172^{\star \star \star}$ & $-3.3839 * \star \star$ & $-8.3009 * \star \star$ & $-10.6136^{\star \star \star}$ & $-1.9064^{\star \star \star}$ & $-25.7527^{\star \star \star}$ & $-15.6255^{\star \star \star}$ \\
\hline & 0.0781 & 0.2852 & 0.3355 & 0.0824 & 0.5122 & 0.5702 & 0.0176 & 0.3568 & 0.4297 \\
\hline \multirow[t]{2}{*}{ Baa } & $1.0849^{\star \star \star}$ & $1.1121^{\star \star \star}$ & $1.1182^{\star \star \star}$ & $1.0418^{\star \star \star}$ & $1.0367^{\star \star \star}$ & $1.1168^{\star \star \star}$ & $1.1585^{\star \star \star}$ & $1.1516^{\star \star \star}$ & $1.1845^{\star \star \star}$ \\
\hline & 0.0139 & 0.0138 & 0.0140 & 0.0421 & 0.0417 & 0.0432 & 0.0154 & 0.0151 & 0.0155 \\
\hline \multirow[t]{2}{*}{$\mathrm{Ba}$} & $1.5241^{\star \star \star}$ & $1.5944^{\star \star \star}$ & $1.5976^{\star \star \star}$ & $1.5260^{* * *}$ & $1.5595^{\star \star \star}$ & $1.6511^{\star \star *}$ & $1.5786^{* \star *}$ & $1.6101^{* \star *}$ & $1.6337^{\star * \star}$ \\
\hline & 0.0170 & 0.0173 & 0.0175 & 0.0430 & 0.0432 & 0.0454 & 0.0197 & 0.0197 & 0.0202 \\
\hline \multirow[t]{2}{*}{ B } & $1.7323^{* \star *}$ & $1.8604^{\star \star \star}$ & $1.8897^{* \star *}$ & $1.7317^{\star * \star}$ & $1.8248^{\star \star \star}$ & $1.9094^{\star * \star}$ & $1.7911^{* * *}$ & $1.8360^{* \star *}$ & $1.9216^{* \star *}$ \\
\hline & 0.0215 & 0.0225 & 0.0228 & 0.0458 & 0.0474 & 0.0491 & 0.0264 & 0.0266 & 0.0279 \\
\hline \multirow[t]{2}{*}{ Caa } & $3.0060^{\star \star *}$ & $2.8240^{\star \star \star}$ & $3.1527^{\star \star \star}$ & $2.6315^{\star \star \star}$ & $2.8019^{\star \star *}$ & $2.7880^{\star \star \star \star ~}$ & $3.1612^{\star \star \star}$ & $2.7189^{\star \star \star \star}$ & 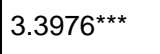 \\
\hline & 0.0417 & 0.0397 & 0.0437 & 0.0604 & 0.0628 & 0.0629 & 0.0612 & 0.0518 & 0.0688 \\
\hline \multirow[t]{2}{*}{ TSO } & $-0.2554^{\star \star \star}$ & & $-0.1692^{\star \star \star}$ & $0.0274^{\star \star *}$ & & $0.0644^{\star \star \star}$ & $-0.3807^{\star \star \star}$ & & 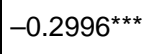 \\
\hline & 0.0042 & & 0.0049 & 0.0057 & & 0.0062 & 0.0055 & & 0.0063 \\
\hline \multirow[t]{2}{*}{ SVO } & & $0.7006^{\star \star \star}$ & $0.4759^{\star \star \star}$ & & $0.2062^{\star \star \star}$ & $0.2901^{\star \star \star}$ & & $0.8718^{\star \star \star}$ & $0.5094^{\star \star \star}$ \\
\hline & & 0.0109 & 0.0129 & & 0.0206 & 0.0224 & & 0.0133 & 0.0159 \\
\hline $\begin{array}{l}\text { Year } \\
\text { Dummies }\end{array}$ & Yes & Yes & Yes & Yes & Yes & Yes & Yes & Yes & Yes \\
\hline $\begin{array}{l}\text { Pseudo } \\
\text { R-square }\end{array}$ & 0.1360 & 0.1364 & 0.1400 & 0.0195 & 0.0200 & 0.0204 & 0.2031 & 0.1933 & 0.2103 \\
\hline $\begin{array}{l}\text { R-square } \\
\text { rescaled }\end{array}$ & 0.4755 & 0.4767 & 0.4895 & 0.3213 & 0.3285 & 0.3362 & 0.4305 & 0.4098 & 0.4458 \\
\hline AUROC & 0.9399 & 0.9376 & 0.9424 & 0.9184 & 0.9181 & 0.9187 & 0.8953 & 0.8790 & 0.9008 \\
\hline
\end{tabular}

This table shows parameter estimates for the probit model Model 13 to Model 21 . The model specification is $P\left(D_{i j t}=1\right)=\Phi\left(\beta^{\prime} \chi_{i j t}\right)$. Standard errors are in parentheses. The significance is indicated as follows: ***: significant at $1 \%,{ }^{*}$ : significant at $5 \%, *$ : significant at $10 \%$. AUROC is the area under the receiver operating characteristic curve (see Agresti (1984)).

The first panel (all years) shows that the impairment risk given ratings (ie which is not explained by ratings) decreases with time since origination. This confirms that CRAs may have an incentive to assign i) too low risk ratings in origination years to increase fee revenue and ii) too high risk ratings in monitoring years to maintain stable default and rating migration performance measures. The second and third panel show that this effect is mainly driven by occurrence of the GFC. In addition, impairment risk given ratings increases with the securitization activity at origination. This result holds for all years, the years before and during the GFC.

Table 9 shows that the negative parameter estimate (panel for all years) for the time since origination (TSO) implies that the level of impairment risk (given the rating) decreases over

25 High SVO indicates that a tranche was originated in a high securitization volume year (ie especially 2002 and later). Low SVO indicates that a tranche was originated in a low securitization volume year (ie especially before 2002). 
time. The relative fee revenue is high at origination and low thereafter. The implication is that the impairment risk given ratings (ie which is not explained by ratings) decreases over time. This confirms that CRAs may have an incentive to assign i) too low risk ratings in origination years to increase fee revenue and ii) too high risk ratings in monitoring years to maintain stable default and rating migration performance measures. The second and third panel show that this effect is mainly driven by the occurrence of the GFC. Thus we reject the hypothesis $\mathrm{H} 2 \mathrm{a}$ that rating-implied impairment risk and time since origination are positively correlated.

In addition, a high securitization volume at origination (when absolute fee revenue is high) implies high impairment risk after controlling for rating. This result holds for the years before and during the GFC. Thus we reject the hypothesis $\mathrm{H} 2 \mathrm{~b}$ that rating-implied impairment risk and rating intensity at origination are negatively correlated.

Both hypothesis tests suggest that impairment risk is under-represented by ratings when fee revenue is high, which is the case at origination and during an economic boom when origination volume is high.

\subsection{H3 - Prediction hypothesis}

Ratings are generally applied as proxies for future impairment risk. The information content of corporate bond issue ratings has been analysed (compare, eg, Blume et al (1998)). However, no evidence for CRA ratings on securitizations has been presented. Our previous results show that credit ratings do not include all relevant risk factors and are overoptimistic when fee revenue is high. Therefore we now check how this affects the ability for predicting future impairment risk.

The forecasting power of credit ratings is tested by an approach related to (Rajan et al (2008)) which directly links ratings to future impairment risk. The approach proceeds in three steps.

Firstly, a probit regression is estimated for each year

$$
P\left(D_{i j t}=1\right)=\Phi\left(\beta^{\prime} \chi_{i j t}\right)
$$

where $\chi_{j i t}$ are dummy variables for the ratings, which are observed at the beginning of the observation period. Next, the linear predictor for the subsequent year is calculated:

$$
\hat{\eta}_{i j t+1}=\hat{\beta}^{\prime} \chi_{i j t+1}
$$

and the impairment probability prediction for the subsequent year

$$
\hat{p}_{i j t+1}=\Phi\left(\hat{\beta}^{\prime} \chi_{i j t+1}\right)
$$

using the estimated coefficients $\hat{\beta}$ from Equation (4). Finally, the forecasting power is assessed by running a probit regression (Model 22).

$$
P\left(D_{i j t+1}=1\right)=\Phi\left(\gamma_{0}+\gamma_{1} \hat{\eta}_{i j t+1}\right)
$$

We test for $\gamma_{0}=0$ and $\gamma_{1}=1$, i.e., whether ratings provide perfect forecasts. As a robustness check a linear regression is estimated (Model 23):

$$
D_{i j t+1}=\delta_{0}+\delta_{1} \cdot \hat{p}_{i j t+1}+\varepsilon_{i j t+1}
$$

so that $E\left(D_{i j t+1}\right)=P\left(D_{i j t+1}\right)=\delta_{0}+\delta_{1} \cdot \hat{p}_{i j t+1}$ where $\delta_{0}=0$ and $\delta_{1}=1$.

Again, we test for $\delta_{0}=0$ and $\delta_{1}=1$. All steps are repeated for each year from 1999 to 2008 where in the probit regression (4) all data up to year $t$ are used. Table 10 shows the 
parameter estimates from each regression Model 22 (Equation 7). Table 11 contains the estimation results from each regression Model 23 (Equation 8).

Table 10

The link between realized and predicted impairment risk (probit regression)

\begin{tabular}{|c|c|c|c|c|c|}
\hline & (1) & (2) & (3) & (4) & (5) \\
\hline Prediction year & $\gamma_{0}$ & $\gamma_{1}$ & Pseudo $R^{2}$ & $R^{2}$ Rescaled & AUROC \\
\hline 1999 & $\begin{array}{c}-0.7917^{\star \star \star} \\
(0.1668)\end{array}$ & $\begin{array}{l}0.6206^{\star \star \star} \\
(0.0587)\end{array}$ & 0.0079 & 0.741 & 0.851 \\
\hline 2000 & $\begin{array}{c}0.1750 \\
(0.2309)\end{array}$ & $\begin{array}{c}1.1776 \\
(0.1210)\end{array}$ & 0.0158 & 0.3852 & 0.949 \\
\hline 2001 & $\begin{array}{c}-0.1547 \\
(0.1321)\end{array}$ & $\begin{array}{l}0.8558^{\star \star \star} \\
(0.0540)\end{array}$ & 0.0180 & 0.2607 & 0.905 \\
\hline 2002 & $\begin{array}{l}0.5501^{\star \star \star} \\
(0.1160)\end{array}$ & $\begin{array}{c}1.1008^{*} \\
(0.0529)\end{array}$ & 0.0375 & 0.3328 & 0.926 \\
\hline 2003 & $\begin{array}{r}-0.1045 \\
(0.0995)\end{array}$ & $\begin{array}{c}0.9276 \\
(0.0482)\end{array}$ & 0.0271 & 0.2896 & 0.913 \\
\hline 2004 & $\begin{array}{c}-0.6379^{\star \star \star} \\
(0.0820)\end{array}$ & $\begin{array}{l}0.6700^{\star \star \star} \\
(0.0351)\end{array}$ & 0.0193 & 0.1916 & 0.821 \\
\hline 2005 & $\begin{array}{c}-0.3331^{\star \star} \\
(0.1376)\end{array}$ & $\begin{array}{l}1.1792^{\star *} \\
(0.0854)\end{array}$ & 0.0131 & 0.3553 & 0.958 \\
\hline 2006 & $\begin{array}{c}0.2745^{\star} \\
(0.1596)\end{array}$ & $\begin{array}{l}1.5383^{\star \star \star} \\
(0.1008)\end{array}$ & 0.0121 & 0.4276 & 0.941 \\
\hline 2007 & $\begin{array}{l}0.6017^{\star \star \star} \\
(0.0493)\end{array}$ & $\begin{array}{l}0.9468^{\star \star \star} \\
(0.0192)\end{array}$ & 0.0442 & 0.2127 & 0.839 \\
\hline 2008 & $\begin{array}{l}1.4974^{\star \star *} \\
(0.0252)\end{array}$ & $\begin{array}{l}0.9788^{\star *} \\
(0.0098)\end{array}$ & 0.1453 & 0.2482 & 0.750 \\
\hline
\end{tabular}

This table shows the results of out-of-sample prediction probit regression Model 22. The model specification is $P\left(D_{i j t+1}=1\right)=\Phi\left(\gamma_{0}+\gamma_{1} \hat{\eta}_{i j t+1}\right)$. Standard errors are in parentheses. The significance is indicated as follows:

***: significant at $1 \%$, **: significant at $5 \%$, *: significant at $10 \%$. The tested hypotheses are that $\gamma_{0}=0$ and $\gamma_{1}=1$

The estimated parameters $\gamma_{0}$ and $\gamma_{1}$ are statistically different from $\gamma_{0}=0$ and $\gamma_{1}=1$. The ramification is that CRA ratings do not predict impairment risk. 
Table 11

The link between realized and predicted impairment risk (linear regression)

\begin{tabular}{|c|c|c|c|}
\hline & (1) & (2) & (3) \\
\hline Prediction year & $\delta_{0}$ & $\delta_{1}$ & Adj. $R^{2}$ \\
\hline 1999 & $\begin{array}{l}0.0014^{\star \star \star} \\
(0.0005)\end{array}$ & $\begin{array}{l}0.6513^{\star \star \star} \\
(0.0410)\end{array}$ & 0.0178 \\
\hline 2000 & $\begin{array}{l}-0.0018^{\star \star \star} \\
(0.0004)\end{array}$ & $\begin{array}{l}1.1613^{\star \star *} \\
(0.0284)\end{array}$ & 0.1009 \\
\hline 2001 & $\begin{array}{l}0.0029 * \star \star \\
(0.0006)\end{array}$ & $\begin{array}{l}0.6721^{\star * *} \\
(0.0319)\end{array}$ & 0.0265 \\
\hline 2002 & $\begin{array}{l}0.0024^{\star \star \star} \\
(0.0008)\end{array}$ & $\begin{array}{l}1.6082^{\star \star \star} \\
(0.0435)\end{array}$ & 0.0678 \\
\hline 2003 & $\begin{array}{l}0.0007 \\
(0.0006)\end{array}$ & $\begin{array}{l}0.9589 * \star \star \\
(0.0262)\end{array}$ & 0.0587 \\
\hline 2004 & $\begin{array}{l}0.0001 \\
(0.0007)\end{array}$ & $\begin{array}{l}0.9407^{\star \star \star} \\
(0.0230)\end{array}$ & 0.0683 \\
\hline 2005 & $\begin{array}{l}-0.0017^{\star \star \star} \\
(0.0003)\end{array}$ & $\begin{array}{l}0.4375^{\star \star} \\
(0.0106)\end{array}$ & 0.0567 \\
\hline 2006 & $\begin{array}{l}-0.0024^{\star \star \star} \\
(0.0002)\end{array}$ & $\begin{array}{l}0.6031^{* * *} \\
(0.0103)\end{array}$ & 0.0768 \\
\hline 2007 & $\begin{array}{l}0.0155^{\star \star \star} \\
(0.0007)\end{array}$ & $\begin{array}{l}1.7140 * \star * \\
(0.0391)\end{array}$ & 0.0322 \\
\hline 2008 & $\begin{array}{l}0.0925^{\star \star \star} \\
(0.0014)\end{array}$ & $\begin{array}{l}5.1955^{\star * *} \\
(0.0467)\end{array}$ & 0.1573 \\
\hline
\end{tabular}

This table shows the results of out-of-sample prediction linear regression Model 23. The model specification is $D_{i j t+1}=\delta_{0}+\delta_{1} \cdot \hat{p}_{i j t+1}+\varepsilon_{i j t+1}$. Standard errors are in parentheses. The significance is indicated as follows: ***: significant at 1\%, **: significant at $5 \%$, *: significant at $10 \%$. The tested hypotheses are that $\delta_{0}=0$ and $\delta_{1}=1$.

The estimated parameters $\delta_{0}$ and $\delta_{1}$ are statistically different from $\delta_{0}=0$ and $\delta_{1}=1$. The ramification is that CRA ratings do not predict impairment risk.

It can be seen that in most years, both coefficients of either regression are statistically significant and thus different from their ideal values (Columns 1 and 2). Moreover, the respective $R^{2} \mathrm{~s}$ neither increase nor decrease throughout. This implies that the ratings 
quality has neither consistently declined nor improved. ${ }^{26}$ While for most years, the evidence of underprediction or overprediction is mixed, particularly the downturn years 2002, 2007 and 2008 exhibit a significant underestimation of risk by the ratings. If ratings predict impairment risk accurately, they should have anticipated the downturns and should have downgraded the transactions accordingly. However, the observation that the estimates of $\gamma_{0}$ and $\delta_{0}$ are greater than zero indicates that impairment risk has been under-predicted by the ratings in these years. In summary, the analysis shows that the rating quality has neither consistently declined nor improved through time. In other words, there has been a mix of years of overprediction and years of underprediction of impairment risk. This indicates that CRA ratings have a limited ability to predict impairment risk.

In summary, we reject the hypothesis $\mathrm{H} 3$ that ratings predict impairment risk. The ramifications are that CRAs are poor predictors for impairment risk and that investors relying on predictions of future levels of impairment risk may have to build private models. ${ }^{27}$ Alternatively, CRAs may adjust their ratings by a projection of the future state of the economy. This may be accomplished by including time-lagged variables of the level and change of the total impairment rate.

\section{Discussion and outlook}

To date, empirical evidence on the accuracy of ratings and risk models for securitizations is limited. The article's main objective is to analyze the impact of idiosyncratic and systematic risk characteristics on impairment risk of securitizations.

The most substantial findings are that CRA ratings for securitizations

- Do not fully account for the average credit quality in asset portfolios;

- Do not fully account for the structure of asset securitizations;

- $\quad$ Measure a too low impairment risk level at origination when fee revenue is high;

- $\quad$ Measure a too low impairment risk level if a securitization was originated in a high securitization activity year;

- $\quad$ Are unable to predict impairment risk.

CRA ratings (like many other commercial vendor solutions) may have to be interpreted in relation to the invested resources. Please note that the major CRAs cover a large number of rated debt issuers and issues per year ${ }^{28}$ with a limited number of financial analysts. ${ }^{29}$ This paper has also shown that ratings are informative with regard to the average idiosyncratic impairment risk over the business cycle.

There may be various ways to address the findings of this paper, which may include the knowledge transfer to the financial system (ie to CRAs and CRA rating users), independence between CRA fee revenue and origination process, cap for CRA fee revenues or introduction

26 A comparison of $R^{2}$ should be carefully interpreted as each year has a different number of observations. Please also note that our definition of rating quality differs from the definition of rating standard by Blume et al (1998), compare Footnote 10.

27 The results confirm the findings by Loeffler (2004) for corporate ratings.

28 For instance, in 2007, Moody's Investors Service rated 100 sovereigns; 12,000 corporate issuers; 29,000 public finance issues; and 96,000 structured finance obligations.

29 For instance, in 2007, Moody's Investors Service employed approximately 1,000 analysts. 
of minimum standards on resources spent on ratings. A public discussion is needed to transfer the findings into regulatory policy.

To date, CRAs have usually made available to the general public histories of their financial risk measures as well as the respective realizations. Little is known of the quality of models of other vendors as well as financial institution internal models as the respective information is kept private. However, recent negative earnings announcements from financial institutions suggest that other models applied in industry may share similar properties. Therefore, a formal validation of such models is important.

\section{References}

Acharya, V V, S T Bharath and A Srinivasan (2007): "Does industry-wide distress affect defaulted firms? - Evidence from creditor recoveries", Journal of Financial Economics, vol 85, pp 787-821.

Agresti, A (1984), "Analysis of Ordinal Categorical data", Wiley, New York.

Altman, E, B Brady, A Resti and A Sironi (2005): "The link between default and recovery rates: Theory, empirical evidence and implications", Journal of Business, vol 78, pp 2203-27.

Becker, B and T Milbourn (2008): "Reputation and competition: Evidence from the credit rating industry", Harvard Business School Working Paper, No. 09-051, October 2008.

Benmelech, E and J Dlugosz (2008): "The alchemy of CDO credit ratings", Working Paper, Harvard University.

Blume, M, F Lim and A MacKinlay (1998): "The declining credit quality of U.S. corporate debt: Myth or reality?", Journal of Finance, vol 53, pp 1389-413.

Bolton, P, X Freixas and J Shapiro (2009): "The credit ratings game", Working Paper 14712, National Bureau of Economic Research.

Carey, M (1998): "Credit risk in private debt portfolios", Journal of Finance, vol 53, pp 1363-87.

Carey, M and M Hrycay (2001): "Parameterizing credit risk models with rating data", Journal of Banking and Finance, vol 25, pp 197-270.

Crouhy, M, D Galai and R Mark (2001): "Prototype risk rating system", Journal of Banking and Finance, vol 25, pp 47-95.

Crouhy, M, R Jarrow and S Turnbull (2008): "The Subprime Credit Crisis of 07", Working Paper, University of Houston, Natixis and Cornell University.

Dichev, I and J Piotroski (2001): "The long-run stock returns following bond ratings changes", Journal of Finance, vol 56, pp 173-203.

Dietsch, M and J Petey (2004): "Should SME exposures be treated as retail or corporate exposures? a comparative analysis of default probabilities and asset correlations in French and German SMEs", Journal of Banking and Finance, vol 28, pp 773-88.

Duffie, D, L Saita and K Wang (2007): "Multi-period corporate default prediction with stochastic covariates", Journal of Financial Economics, vol 83, pp 635-65.

Duffie, D and K Singleton (1999): "Modeling term structures of defaultable bonds", Review of Financial Studies, vol 12, pp 687-720.

Ederington, L H and J C Goh (1993): "Is a bond rating downgrade bad news, good news, or no news for stockholders?", Journal of Finance, vol 48, pp 2001-8. 
Fitch Ratings (2006), "Exposure draft: Introducing the Fitch VECTOR Default Model Version 3.0".

Franke, G and J Krahnen (2008): "The future of securitization", Working Paper, Frankfurt Center for Financial Studies.

Gordy, M (2000): "A comparative anatomy of credit risk models", Journal of Banking and Finance, vol 24, pp 119-49.

(2003): "A risk-factor model foundation for ratings-based bank capital rules", Journal of Financial Intermediation, vol 12, pp 199-232.

Grunert, J, L Norden and M Weber (2005), "The role of non-financial factors in internal credit ratings", Journal of Banking and Finance, vol 29, pp 509-31

Grunert, J and M Weber (2009): "Recovery rates of commercial lending: Empirical evidence for German companies", Journal of Banking and Finance, vol 33, pp 505-13.

Gupton, G, C Finger and M Bhatia (1997): "CreditMetrics technical document", J.P. Morgan.

Hellwig, M (2008): "Systemic risk in the financial sector: An analysis of the SubprimeMortgage Financial Crisis", Working Paper, Max Planck Institute for Research on Collective Goods.

Hull, J (2009): "The credit crunch of 2007: What Went Wrong? Why? What Lessons Can Be Learned?", Journal of Credit Risk, vol 5, pp 3-18.

Hull, J and A White (2004): "Valuation of a CDO and nth to default CDS without monte carlo simulation", Journal of Derivatives, vol 12, pp 8-23.

Jarrow, R, D Lando and S Turnbull (1997): "A Markov model for the term structure of credit risk spreads", Review of Financial Studies, vol 10, pp 481-523.

Jarrow, R and S Turnbull (1995): "Pricing derivatives on financial securities subject to credit risk", Journal of Finance, vol 50, pp 53-85.

Jorion, P, Z Liu and C Shi (2005): "Informational effects of regulation fd: Evidence from rating agencies", Journal of Financial Economics, vol 76, pp 309-30.

Koopman, S, A Lucas and P Klaassen (2005): "Empirical credit cycles and capital buffer formation", Journal of Banking and Finance, vol 29, pp 3159-79.

Krahnen, J and M Weber (2001): "Generally accepted rating principles: a primer", Journal of Banking and Finance, vol 25, pp 3-23.

Leland, H (1994): "Corporate debt value, bond covenants and optimal capital structure", Journal of Finance, vol 49, pp 1213-52.

Leland, H and K Toft (1996): "Optimal capital structure, endogeneous bankruptcy, and the term structure of credit spreads", Journal of Finance, vol 51, pp 987-1019.

Leot, P, D Arber and L Schou-Zibell (2008): "Securitisation in east asia", Asian Development Bank Working Paper Series on Regional Economic Integration.

Loeffler, G (2004): "An anatomy of rating through the cycle", Journal of Banking and Finance, vol 28, pp 695-720.

Longstaff, F and A Rajan (2008): "An empirical analysis of the pricing of collateralized debt obligations", Journal of Finance, vol 63, pp 529-63.

Longstaff, F and E Schwartz (1995): "A simple approach to valuing risky fixed and floating rate debt", Journal of Finance, vol 50, pp 789-819.

Madan, D and H Unal (1995): "Pricing the risk of recovery in default with apr violation", Journal of Banking and Finance, vol 27, pp 1001-218. 
Mayer, C, K Pence and S Sherlund (2008): "The rise in mortgage defaults: Facts and myths", forthcoming in Journal of Economic Perspectives.

McNeil, A and J Wendin (2007): "Bayesian inference for generalized linear mixed models of portfolio credit risk", Journal of Empirical Finance, vol 14, pp 131-49.

Merton, R C (1974): "On the pricing of corporate debt: The risk structure of interest rates", Journal of Finance, vol 29, pp 449-70.

Miu, P and B Ozdemir (2002): "Rating banks, risk and uncertainty in an opaque industry", American Economic Review, vol 92, pp 874-88.

Moody's Investors Service (2006), "CDOROM v2.3 user guide".

(2008), "Default and loss rates of structured finance securities: 1993-2007".

Pan, J and K Singleton (2008): "Default and recovery implicit in the term structure of sovereign cds spreads", Journal of Finance, vol 68, pp 2345-84.

Purda, L (2007): "Stock market reactions to anticipated versus surprise rating changes", Journal of Financial Research, vol 30, pp 301-20.

Qi, M and X Yang (2009): "Loss given default of high loan-to-value residential mortgages", Journal of Banking and Finance, vol 33, pp 788-99.

Radelet, S and J Sachs (1998): "The East Asian Financial Crisis: Diagnosis, remedies, prospects", Brookings Papers, vol 28, pp 1-90.

Rajan, U, A Seru and V Vig (2008): "The failure of models that predict failure: distance, incentives and defaults", Working paper, University of Michigan, University of Chicago and London Business School.

Shumway, T (2001): "Forecasting bankruptcy more accurately: a simple hazard-rate model", Journal of Business, vol 74, pp 101-24.

Standard and Poor's (2005), "CDO Evaluator Version 3.0: Technical document". 